\title{
Use of the CALIOP vertical feature mask for evaluating global aerosol models
}

\author{
E. P. Nowottnick ${ }^{1,2}$, P. R. Colarco ${ }^{2}$, E. J. Welton ${ }^{3}$, and A. da Silva ${ }^{4}$ \\ ${ }^{1}$ GESTAR/Universities Space Research Association, Columbia, MD, 21046, USA \\ ${ }^{2}$ Atmospheric Chemistry and Dynamics Laboratory, Code 614, NASA GSFC, Greenbelt, MD, 20771, USA \\ ${ }^{3}$ Mesoscale Atmospheric Processes Laboratory, Code 612, NASA GSFC, Greenbelt, MD, 20771, USA \\ ${ }^{4}$ Global Modeling and Assimilation Office, Code 610.1, NASA GSFC, Greenbelt, MD, 20771, USA \\ Correspondence to: E. P. Nowottnick (edward.p.nowottnick@ nasa.gov)
}

Received: 24 November 2014 - Published in Atmos. Meas. Tech. Discuss.: 30 January 2015

Revised: 11 August 2015 - Accepted: 12 August 2015 - Published: 9 September 2015

\begin{abstract}
We use observations from the space-based CloudAerosol Lidar with Orthogonal Polarization (CALIOP) to evaluate global aerosol distributions simulated in the NASA Modern Era Retrospective Analysis for Research and Applications aerosol reanalysis (MERRAero). We focus particularly on an evaluation of aerosol types, using the CALIOP vertical feature mask (VFM) algorithm, and look especially at Saharan dust distributions during July 2009. MERRAero consists of an aerosol simulation produced in the Goddard Earth Observing System version 5 (GEOS-5) Earth system model and incorporates assimilation of MODIS-derived aerosol optical thickness (AOT) to constrain column aerosol loadings. For comparison to the CALIOP VFM we construct two synthetic VFMs using the MERRAero aerosol distributions: a CALIOP-like VFM in which we simulate the total attenuated backscatter and particle depolarization ratio from the MERRAero output and pass those into the CALIOP VFM typing algorithm (MERRAero-CALIOP), and an extinctionbased VFM in which we use the MERRAero-simulated species-resolved extinction to map the MERRAero species to the CALIOP VFM types (MERRAero-Extinction). By comparing the MERRAero-CALIOP VFM to CALIOP VFM, we can diagnose the aerosol transport and speciation in MERRAero. By comparing the MERRAero-CALIOP and MERRAero-Extinction-simulated VFM, we perform a simple observing system experiment (OSE), which is useful for identifying limitations of the CALIOP VFM algorithm itself. We find that, despite having our column AOT constrained by MODIS, comparison to the CALIOP VFM reveals a greater occurrence of dusty aerosol layers in our
\end{abstract}

MERRAero-CALIOP VFM due to errors in MERRAero aerosol speciation. Additionally, we find that the CALIOP VFM algorithm is challenged when classifying aerosol features when multiple aerosol types are present, as our application of the CALIOP VFM algorithm to MERRAero aerosol distributions classified marine-dominated aerosol layers with low aerosol loadings as polluted dust when the contribution of dust to the total extinction was low.

\section{Introduction}

Mineral dust aerosols directly affect Earth's atmospheric radiative balance by absorbing and scattering light (Colarco et al., 2014a; Ryder et al., 2013; Balkanski et al., 2007; Zhu et al., 2007; Haywood et al., 2003; Tegen and Miller, 1998; Sokolik and Toon, 1996). Dust particles also act as cloud condensation (Kumar et al., 2009; Rosenfeld et al., 2001) and ice (Koehler et al., 2010; DeMott et al., 2003) nuclei, altering the microphysical properties - and, hence, radiative properties - of clouds and modulating precipitation (Jenkins et al., 2008; Yoshioka et al., 2007; Rosenfeld et al., 2001). Furthermore, because of its radiative impacts, dust may affect tropical storm dynamics by enhancing atmospheric stability and inducing low-level wind shear that is not favorable for storm development (Reale et al., 2009, 2014; Dunion and Velden, 2004), with observational evidence suggesting that tropical storm activity and Saharan dust events are anti-correlated (Lau and Kim, 2007; Evan et al., 2006). Additionally, longrange transport and subsequent deposition of dust serve as a 
source of iron to terrestrial (Swap et al., 1992) and aquatic ecosystems (Mahowald et al., 2009), which in the latter case can enhance atmospheric $\mathrm{CO}_{2}$ uptake by phytoplankton in iron-limited oceans (Jickells et al., 2005). Understanding of the roles of dust in all of these processes remains incomplete owing to the heterogeneous spatial, temporal, and compositional nature of dust and other related aerosols, and overall aerosol interactions within the Earth system remain a driving source of uncertainty in assessing the current climate and projecting future climate (IPCC, 2014).

Global aerosol distributions are typically observed and quantified in terms of their optical properties, particularly aerosol optical thickness (AOT), a column measure of the aerosol loading. AOT is readily measured by ground-based sun photometers (e.g., the Aerosol Robotic Network, or AERONET; Holben et al., 1998) and is a primary retrieval of space-based sensors such as those from the Moderate Resolution Imaging Spectroradiometer (MODIS; Remer et al., 2005; Levy et al., 2010) and the Multi-angle Imaging Spectroradiometer (MISR; Kahn et al., 2005). However, owing to limitations of spatial (e.g., AERONET) and temporal (e.g., MODIS) resolution, as well as challenges in isolating dust from the total aerosol loading, global aerosol transport models serve as useful tools to complement an incomplete observing system, by simulating the aerosol source, sink, and chemistry processes that impact the aerosol loading (Kim et al., 2014; Colarco et al., 2010; Textor et al., 2006; Kinne et al., 2006). Because of their high temporal and spatial resolution, the aerosol distributions simulated in aerosol data assimilation systems have the potential to fill in gaps in the existing observing systems. Global aerosol transport models are also used to provide aerosol forecasts, which have numerous applications, ranging from air quality forecasts in the near term to simulating aerosol distributions for various climate scenarios on longer timescales. However, the current lack of uncertainty characterization limits the utility of global aerosol transport models (Huneuus et al, 2011; Textor et al., 2006; Kinne et al., 2006). Recently a number of modeling groups have adopted data assimilation capabilities to formally constrain the simulated AOT with observations from sensors such as MODIS (e.g., Sessions et al., 2015; Benedetti et al., 2009; Zhang et al., 2008). While it is a useful firstorder constraint, assimilation of single-channel visible AOT observations do not correct uncertainty associated with speciation and vertical distributions of aerosols. Uncertainties in the speciation and vertical structure of aerosols have significant implications for characterizing aerosol transport pathways, quantifying loss processes, and understanding aerosolEarth system interactions (e.g., impacts of aerosols on cloud lifetimes; aerosol radiative forcing) that are sensitive to the vertical location of specific types of aerosol.

Important information about the vertical distributions of aerosols has long been available from ground-based (e.g., Huang et al., 2010; Johnson et al., 2008; Papayannis et al., 2005; Matthias et al., 2004; Reid et al., 2003; Campbell et al., 2002; Welton et al., 2000, 2001) and airborne (e.g., Rogers et al., 2009; Esselborn et al., 2009; Reid et al., 2003; McGill et al., 2002; Browell et al., 1997; Browell et al., 1983) lidar systems, but by their nature these systems have limited spatial and temporal coverage. The launch of the space-based Cloud-Aerosol Lidar with Orthogonal Polarization (CALIOP) aboard the Cloud-Aerosol Lidar and Infrared Pathfinder Satellite Observations (CALIPSO) satellite on 28 April 2006 vastly increased the spatial and temporal coverage of aerosol and cloud vertical profiles (Winker et al., 2009). As part of NASA's “A-Train” (L'Ecuyer and Jiang, 2010) constellation of satellites, CALIPSO flies in formation with a number of other satellites, providing opportunities for coordinated multi-sensor retrievals of aerosol properties.

CALIOP provides daytime and nighttime attenuated backscatter profiles at 532 and $1064 \mathrm{~nm}$, as well as information about depolarization at $532 \mathrm{~nm}$. This information is first used to discriminate cloud and aerosol layers (Liu et al., 2005). Aerosol layers are then fed through a vertical feature mask (VFM) algorithm that assigns aerosol type classifications based on aerosol geographic location, the underlying surface type, observed aerosol altitude, attenuated backscatter, and depolarization ratio. The practical application of the CALIOP VFM is to assign an appropriate lidar ratio for each detected aerosol layer in order to compute aerosol extinction profiles from the attenuated backscatter signals, extinction being more directly comparable to model fields than attenuated backscatter (Omar et al., 2009). By itself, though, the VFM also provides a unique tool for directly exploring the vertical distribution of cloud and aerosol layers, as well as aerosol composition, but its full potential has not yet been explored. Hagihara et al. (2010) and Yoshida et al. (2010) have used the cloud component of the VFM to determine the vertical distribution of ice and water clouds. Adams et al. (2012) and Chen et al. (2012) have used the aerosol component of the CALIOP VFM to classify the global three-dimensional distribution of specific aerosol types. Tesche et al. (2013) compared ground-based Raman lidar measurements at Cabo Verde (under the Saharan dust plume) with near-coincident CALIOP overpasses, finding generally good agreement in the $532 \mathrm{~nm}$ backscatter coefficient and particle depolarization ratios, but sensitivity in the VFM-determined aerosol classification, which they attributed to residual molecular contributions to the computed particle depolarization ratio, leading to incorrect assignment of lidar ratio for extinction calculations. Mielonen et al. (2009) classified aerosol types from ground-based AERONET single-scattering albedo (SSA) and Ångström exponent (AE) retrievals, finding best consistency between the AERONET-determined types and near-coincident CALIOP VFM-reported types for the CALIOP dust (AERONET coarse/absorbing) and polluted dust (mixed, coarse and fine/absorbing) classifications. Recently, Burton et al. (2013) evaluated CALIOP VFM aerosol typing using airborne High Spectral Resolution Lidar (HSRL) under-flights, finding classification agreement 
in $80 \%$ of the CALIOP-identified dust cases, but generally worse agreement in the typing for other species. However, despite its utility as a tool for evaluating aerosol type, as far as we know no prior study has used the VFM to evaluate three-dimensional distributions of aerosol type in the context of a global model at monthly timescales.

In this paper, we use the CALIOP VFM to evaluate aerosol speciation and vertical structure in MERRAero, a recently produced aerosol reanalysis based on the Modern Era Retrospective Analysis for Research and Applications (MERRA; Rienecker et al., 2011). MERRAero is produced from a global aerosol simulation made using the NASA Goddard Earth Observing System version 5 (GEOS-5) Earth system model assimilating AOT derived from the MODIS Terra and Aqua observations. Assimilation of AOT constrains the total aerosol loading in MERRAero but not the aerosol speciation or vertical structure. The model output aerosol mass and species distributions are subsequently sampled along the CALIOP ground track, and we compute profiles of aerosol extinction and lidar observables (e.g., total attenuated backscatter, particulate depolarization ratio) using an offline lidar simulator. Two model-based VFM products are constructed from the profiles for comparison to the CALIOP VFM. The first product attempts to closely emulate the CALIPSO VFM by simulating the CALIOP observables (e.g., total attenuated backscatter, estimated particulate depolarization ratio) from assimilated fields and feeding them directly into the CALIOP VFM algorithm (our socalled "MERRAero-CALIOP" method). The second product is a model-derived VFM built by assigning aerosol type classification based on the individual species reported by MERRAero (our "MERRAero-Extinction" method). We focus our analysis on July 2009 over and downwind of the dust-laden Sahara, which is dominated by the CALIOP VFM aerosol type (desert dust) that had best agreement with AERONET (Mielonen et al., 2009) and HSRL (Burton et al., 2013). The objectives of our study are to evaluate the MERRAero aerosol vertical profiles and to investigate the CALIOP VFM-derived aerosol typing in comparison to the known typing information provided by GEOS-5. Our use of two different model-derived VFMs is meant to untangle algorithmic sensitivity embedded in the CALIOP VFM as well as understand the sensitivity of derived aerosol type to assumptions in our simulated aerosol optical properties (e.g., depolarization ratio). Furthermore, this work has implications for assessing the appropriateness of the CALIOP-assigned lidar ratios for extinction calculations. It also lays the groundwork for future lidar-based observing system simulation experiments (OSSEs) and supports new instrument development by simulating fundamental observables.

In Sect. 2, we describe the CALIOP instrument, its measurements, and the VFM product. In Sect. 3 we provide a description of the NASA GEOS-5 aerosol model and the MERRAero aerosol reanalysis, and we provide an assessment of the MERRAero performance in terms of MODIS, MISR, and
AERONET observation. In Sect. 4, we describe our methodology for evaluating MERRAero with the CALIOP VFM and how we construct our model-derived VFMs using MERRAero assimilated fields. Our results are presented in Sect. 5; in Sect. 6 we provide our conclusions.

\section{The CALIOP instrument, feature detection, and vertical feature mask}

\subsection{The CALIOP instrument}

CALIOP provides near-nadir vertical profiles of cloud and aerosol properties onboard the NASA CALIPSO satellite, flying in a sun-synchronous polar orbit in formation with a series of Earth observing systems in the so-called A-Train (L'Ecuyer and Jiang, 2010). CALIOP is a two-wavelength lidar system providing attenuated backscatter data at 532 and $1064 \mathrm{~nm}$ (Winker et al., 2006). Additionally, CALIOP is designed to provide polarization-sensitive data at $532 \mathrm{~nm}$ to gain insight into particle shape (and cloud phase). These data include $532 \mathrm{~nm}$ profiles of parallel and perpendicular (relative to the laser polarization plane) attenuated backscatter. As an active sensor, CALIOP provides information during both the daytime (13:30 local Equator-crossing time) and nighttime (01:30 local Equator-crossing time) (Winker et al., 2006). CALIOP makes measurements with a frequency of $20.16 \mathrm{~Hz}$, yielding a horizontal resolution of $333 \mathrm{~m}$ at the Earth's surface (Winker et al., 2006). The vertical resolution of CALIOP varies, ranging from $300 \mathrm{~m}$ at the top of the CALIOP detection altitude $(30.1-40 \mathrm{~km})$ to $30 \mathrm{~m}$ within the typical altitude range where aerosols are observed near the Earth's surface ( -0.5 to $8.2 \mathrm{~km}$ ) (Winker et al., 2006). Daytime CALIOP observations are affected by solar background illumination, which decreases the signal-to-noise ratio, making the daytime measurements more challenging to interpret. For our analysis we use CALIOP Version 3.01 data. For further information, including instrument specifications, we refer to Winker et al. (2006).

\subsection{Feature detection}

CALIOP Level 1B output includes profiles of attenuated backscatter at 532 and $1064 \mathrm{~nm}$, and the perpendicular component of the backscatter signal at $532 \mathrm{~nm}$ (Winker et al., 2006). This information is input to the CALIOP Level 2 algorithms, which are used to identify and classify cloud and aerosol layers, and retrieve extinction profiles (Vaughan et al., 2005; Liu et al., 2005). The attenuated backscatter is converted to a backscattering ratio, which is the ratio of the observed attenuated backscatter to what is expected in a purely molecular scattering profile. The CALIOP Level 2 featurefinding algorithm searches the backscattering ratio profiles at the nominal 333 horizontal resolution for cloud and aerosol layers, identifying signals or features that are significantly greater than what is expected from the molecular-only pro- 
file (Vaughan et al., 2005). Features with strong backscatter ratios may require only a single lidar pulse for detection. However, fainter features often require horizontal averaging anywhere from 5 to $80 \mathrm{~km}$ along-track to ensure detection in instances when the backscattering ratio is inhomogeneous, varying significantly along the track (Winker et al., 2006). Unfortunately, limitations of this averaging include potentially eliminating important spatial variability in the layer and may result in cloud and aerosol features being averaged together. On the other hand, despite often requiring horizontal averaging for CALIOP Level 2 products, features identified in the vertical by CALIOP are often at horizontal resolutions finer than most global aerosol models, and so they still provide a useful tool for evaluating the vertical location of aerosols in this model.

\subsection{Vertical feature mask}

Once a feature has been identified, the CALIOP featurefinding algorithm utilizes a five-dimensional probability density function (PDF) derived from observed cloud and aerosol properties that input the magnitude of attenuated backscatter, volume depolarization ratio, latitude, altitude, and the color ratio $\chi=\beta^{\prime}{ }_{1064} / \beta^{\prime}{ }_{532}$, defined as the ratio of the attenuated backscatter at $1064 \mathrm{~nm}\left(\beta^{\prime}{ }_{1064}\right)$ and $532 \mathrm{~nm}\left(\beta^{\prime}{ }_{532}\right)$ to distinguish clouds from aerosols (Liu et al., 2010). Compared to aerosols, clouds exhibit enhanced attenuated backscatter values, so features with strong attenuated backscatter values are classified as cloud (Liu et al., 2005). Clouds also have larger particles compared to aerosols, and at CALIOP wavelengths the attenuated backscatter is expected to be spectrally flat, and thus $\chi \approx 1$ (Liu et al., 2005). For aerosols, the attenuated backscatter at $1064 \mathrm{~nm}$ is expected to be less than the attenuated backscatter at $532 \mathrm{~nm}$, so features with $\chi<1$ are classified as aerosol (Liu et al., 2005).

Once an observed feature has been detected and classified as an aerosol, the data are fed to the CALIOP VFM algorithm for further classification into aerosol type (Omar et al., 2009). The CALIOP algorithm assumes representative models of aerosol optical properties based on a multiyear cluster analysis of measurements made by the AERONET of sun photometers (1993-2002) (Omar et al., 2005). The algorithm has models for six aerosol types or mixtures: dust, polluted continental, polluted dust, smoke, clean continental, and clean marine (Omar et al., 2009). Once an observed feature has been identified as aerosol, the attenuated backscatter at $532 \mathrm{~nm}$ is integrated between the feature base and top (Omar et al., 2009):

$\gamma^{\prime}=\int_{z_{\text {top }}}^{z_{\text {base }}} \beta(z) T(z) \mathrm{d} z$,

where $\gamma^{\prime}$ is the integrated total attenuated backscatter at $532 \mathrm{~nm}, \beta$ is the total (molecular + particulate) backscatter at $532 \mathrm{~nm}$ at altitude $(z)$, and $T$ is the total (molecu- lar + particulate) atmospheric transmittance at altitude $(z)$ (Omar et al., 2009).

Additionally, the volume (molecular + particulate) depolarization ratio at $532 \mathrm{~nm}$ is computed as the ratio of the perpendicular to parallel contributions to the total attenuated backscatter (Omar et al., 2009):

$\delta_{\mathrm{v}}^{\prime}=\frac{\sum_{\text {base }}^{z_{\text {top }}} \beta_{\perp}^{\prime}(z)}{\sum_{z_{\text {base }}}^{z_{\text {top }}} \beta_{\mathrm{II}}^{\prime}(z)}$,

where $\delta_{v}^{\prime}$ is the volume depolarization ratio of the feature at $532 \mathrm{~nm}, \beta^{\prime}{ }_{\perp}$ is the perpendicular attenuated backscatter signal at $532 \mathrm{~nm}$ at altitude $(z)$, and $\beta^{\prime}{ }_{I I}$ is the parallel attenuated backscatter signal at altitude $(z)$.

Using the volume depolarization ratio and assuming a molecular depolarization ratio of 0.0036 (Omar et al., 2009), the particulate depolarization ratio is estimated for input into the CALIOP VFM algorithm:

$\delta_{\mathrm{ep}}=\frac{\delta_{\mathrm{v}}^{\prime}\left[(R-1)\left(1+\delta_{\mathrm{m}}\right)+1\right]-\delta_{\mathrm{m}}}{(R-1)\left(1+\delta_{\mathrm{m}}\right)+\delta_{\mathrm{m}}-\delta_{\mathrm{v}}^{\prime}}$,

where $\delta_{\mathrm{ep}}, \delta_{v}^{\prime}$, and $\delta_{m}$ are the estimated particulate, volume, and molecular depolarization ratios at $532 \mathrm{~nm}$, respectively, and $R$ is the mean ratio of the total attenuated backscatter to the molecular backscatter. It should be noted that Eq. (3) is the estimated particulate depolarization ratio and that, in order to obtain the actual particulate depolarization ratio, $R$ is defined as the ratio of the total to molecular backscatter, not the ratio of the total attenuated backscatter (measured by CALIOP) to molecular backscatter. Defining $R$ in this way leads to estimated particulate depolarization ratios that exceed the actual particulate depolarization ratio (Omar et al., 2009; Amiridis et al., 2013). In Sect. 4.2, where we describe our MERRAero-based CALIOP VFM, we are also using an estimated particulate depolarization ratio derived from a version of Eq. (3) to mimic the CALIOP VFM algorithm. We find that using the estimated particulate depolarization ratio vs. the actual particulate depolarization ratio has little impact on our aerosol typing.

Equations (1) and (3) are the calculated properties of the layer that are fed to the CALIOP VFM algorithm (see Table 1). Additionally, the VFM algorithm takes into account the layer altitude, location, elevation and underlying surface type in determining the aerosol type present. An elevated feature is identified if the lowest altitude of the feature begins $500 \mathrm{~m}$ above the Earth's surface or if the feature thickness is greater than $3 \mathrm{~km}$ (Liu et al., 2005). Surface types used in the CALIOP algorithm are from the International GeosphereBiosphere Programme (IGBP) climatology (Loveland et al., 2000). The integrated total attenuated backscatter is used for identifying aerosol type over different land surface regimes in the CALIOP VFM algorithm. The estimated particulate 
Table 1. CALIOP VFM mapping algorithm presented in table form. We refer for Omar et al. (2009) for an algorithm flowchart. “-” indicates that the property of an aerosol layer is not considered in assigning aerosol type.

\begin{tabular}{llrrll}
\hline Pathway & Land surface type & $\begin{array}{r}\text { Attenuated } \\
\left(\mathrm{km}^{-1} \mathrm{sr}^{-1}\right)\end{array}$ & $\begin{array}{r}\text { Depolarization } \\
\text { ratio }\end{array}$ & $\begin{array}{l}\text { Elevated } \\
\text { layer }\end{array}$ & Aerosol type \\
\hline 1 & Snow or ice & $\gamma>0.0015$ & - & - & Clean continental (C) \\
2 & Snow or ice & $\gamma<0.0015$ & - & - & Polluted continental (PC) \\
3 & Land or ocean & - & $0.075<\delta<0.20$ & - & Polluted dust (PD) \\
4 & Land or ocean & - & $\delta>0.20$ & - & Desert dust (DU) \\
5 & Land (desert) & $\gamma<0.0005$ & $\delta<0.075$ & - & Polluted dust (PD) \\
6 & Land (non-desert) & $\gamma<0.0005$ & $\delta<0.075$ & - & Clean continental (C) \\
7 & Land & $\gamma>0.0005$ & $\delta<0.075$ & No & Polluted continental (PC) \\
8 & Ocean & $\gamma<0.01$ & $\delta>0.05$ & - & Polluted continental (PC) \\
9 & Ocean & $\gamma<0.01$ & $\delta<0.05$ & No & Marine (M) \\
10 & Ocean & $\gamma>0.01$ & $\delta<0.075$ & No & Marine (M) \\
11 & Land & $\gamma>0.0005$ & $\delta<0.075$ & Yes & Smoke (SM) \\
12 & Ocean & - & $\delta<0.075$ & Yes & Smoke (SM) \\
\hline
\end{tabular}

depolarization ratio is used to identify non-spherical particles (e.g., dust) or mixtures that contain non-spherical particles (e.g., polluted dust). Surface type (snow or ice, desert, etc.), along with location and altitude (elevated vs. non-elevated aerosol layer) are also used to determine aerosol type in instances when mapping using observables alone is inconclusive. As an example, an elevated aerosol layer with a low particulate depolarization ratio over the Amazon would point to the smoke VFM flag. If the same aerosol layer extended to the surface, the VFM algorithm would point to the polluted continental flag. The CALIOP VFM aerosol types and logic pathways are illustrated in Table 1.

For our analysis, we use the six aerosol types identified in the CALIOP algorithm to validate our model: dust, polluted dust, polluted continental, clean continental, marine and smoke. Additionally, we include flags for clouds and signal attenuation (no signal), the Earth's surface, and instances when the quality assurance flags are equal to zero for the feature type (cloud-aerosol detection failure) or the aerosol feature subtype (aerosol typing failure). For further information into the specifics of the CALIOP VFM algorithm, we refer to Omar et al. (2009).

\section{The NASA GEOS-5 global aerosol transport model}

\subsection{GEOS-5 model description}

GEOS-5 is an Earth system model and data assimilation system developed by the NASA Global Modeling and Assimilation Office (GMAO) that contains components for atmospheric circulation and composition, ocean circulation and biogeochemistry, and land surface processes coupled via the Earth System Modeling Framework (ESMF) (Hill et al., 2004). GEOS-5 is used for studying weather and climate variability, providing high-quality meteorological and chemical analyses for NASA instrument teams and the scien- tific community. Along with traditional meteorological parameters (winds, temperature, etc.) (Rienecker et al., 2008), GEOS-5 includes modules representing atmospheric composition, including aerosols (Colarco et al., 2010) and tropospheric/stratospheric chemical constituents (Pawson et al., 2008), and simulates the radiative impact of these constituents on the atmosphere.

GEOS- 5 may be run at a range of spatial resolutions, from $2^{\circ} \times 2.5^{\circ}$ latitude by longitude to $\sim 3.5 \mathrm{~km} \times 3.5 \mathrm{~km}$ on a cubed-sphere grid (Putman and Suarez, 2011). In the vertical, GEOS-5 has 72 levels on a hybrid-eta coordinate system that is terrain-following near the surface, transitioning to a pressure coordinate above $180 \mathrm{hPa}$, with a model top near $85 \mathrm{~km}$. GEOS-5 may be run in a climate simulation mode, or in a data assimilation mode. For our simulations, we exploit the capability of GEOS-5 to run in replay mode, where, rather than re-running the full meteorological data assimilation system, we replace the dynamical state of the system with a prior data assimilation run. In this analysis, we replay using the MERRA (Rienecker et al., 2011) data set, available every $6 \mathrm{~h}$ at a spatial resolution of $0.5^{\circ} \times 0.625^{\circ}$.

Aerosols in GEOS-5 are treated with a version of the Goddard Chemistry, Aerosol, Radiation, and Transport (GOCART) model (Chin et al., 2002), which has been integrated into the GEOS modeling system as described in Colarco et al. (2010). GOCART treats five aerosol species (dust, sea salt, black carbon, organic carbon, and sulfate), including treatment of source and removal processes and chemistry. GOCART carries five size bins each of dust and sea salt, but otherwise it simulates bulk mass of sulfate and carbonaceous aerosols, the latter of which is partitioned into hydrophobic and hydrophilic modes of black and organic carbon. The treatment of Saharan dust aerosols in particular has been evaluated in Nowottnick et al. $(2010,2011)$ and Colarco et al. (2014a). 
For all species except dust, aerosol optical properties are computed assuming Mie theory, with refractive indices and hygroscopic growth factors primarily from the Optical Properties of Aerosols and Clouds (OPAC) database (Hess et al., 1998) and assumed particle size distributions as in Chin et al. (2002) (for sea salt discretize the particle size distribution across the five size bins and assume the sub-bin particle size distribution from Gong (2003) and hygroscopic growth based on Gerber (1985)). For dust, we use an observationderived set of refractive indices and assume a spheroidal particle shape distribution, following the methodology described in Colarco et al. (2014a) and using the database of nonspherical dust optical properties from Meng et al. (2010).

Aerosol optical properties, whether from Mie theory or the non-spherical dust optical properties database, are presented in look-up tables that provide quantities such as the mass extinction, scattering, and backscattering efficiencies; particulate depolarization ratio; and phase function, as a function of wavelength, relative humidity, and dry particle size. We straightforwardly convert our simulated mass mixing ratios to aerosol optical properties using these tables. Aerosol particulate depolarization ratios are determined from the Legendre polynomial moments of the polarized phase function (for dust only; other species are assumed to have depolarization ratio $=0$ ), and total particulate depolarization ratio is determined by weighting by each aerosol species contribution to scattering. Prior to our construction of our MERRAero VFMs, we found that our simulated particulate depolarization ratios are approximately 0.25 in dusty regions, lower than the observed values of 0.32 (Liu et al., 2008) and 0.31 (Freudenthaler et al., 2009) for Saharan dust events. Sensitivity analyses we performed (not shown here) suggest that our simulated dust depolarization ratio is not strongly sensitive to any errors we have in the simulated dust particle size, as suggested by Freudenthaler et al. (2009), so we speculate here that we are fundamentally limited either because of our assumption that dust particles are ellipsoidal or because of our assumption that they are homogeneous in composition. Imaging of dust particles shows that neither assumption is true (e.g., Buseck and Posfai, 1999), and there is at least theoretical evidence that inclusion of heterogeneity within particles can lead to higher depolarization ratios (Mishchenko et al., 2013). In an attempt to match observed depolarization ratios $(\sim 0.31)$, we therefore increase our simulated dust depolarization ratios by $30 \%$ for our analysis. Finally, as a note about the modeling, this discussion of dust non-sphericity applies only to our optical calculations and is not considered in the simulated transport or removal processes (e.g., sedimentation).

\subsection{Aerosol data assimilation}

Similar to our method of correcting the meteorological state using MERRA, we assimilate column AOT derived from the MODIS instruments onboard the NASA Terra (launched 12
December 1999) and Aqua (launched 4 May 2002) satellites. This AOT assimilation algorithm involves cloud screening and homogenization of the observing system to correct for unresolved biases in the aerosol retrieval products (see Zhang and Reid, 2006). Based on the work of Zhang and Reid (2006) and Lary et al. (2010) we originally developed a back-propagation neural network to correct observational biases in MODIS operational retrievals trained to AERONET coincident observations. We later evolved this system into a neural net type of retrieval that translates cloudcleared MODIS reflectances into AERONET calibrated AOT (referred to hereafter as "MODIS NNR"). In this system, reflectances (instead of retrievals) provide the main input, alongside solar and viewing geometry, MODIS cloud cover, climatological surface albedo and model-derived surface wind speed. Online quality control is performed with the adaptive buddy check of Dee et al. (2001), with observation and background errors estimated using the maximum likelihood approach of Dee and da Silva (1999). The AOT analysis in GEOS-5 is performed by means of analysis splitting where first a two-dimensional analysis of AOT is performed using error covariances derived from differences between observations and the model background (Daley, 1991). Then, the three-dimensional analysis increments (analysis minus first guess) of aerosol mass concentration are computed using an ensemble formulation to represent the background error covariance. This calculation is performed using the Local Displacement Ensemble (LDE) methodology under the assumption that ensemble perturbations (Daley, 1991) are used to represent errors in the placement of the aerosol plumes. These ensemble perturbations are generated with full model resolution, without the need for multiple model runs. It is important to note that the single-channel MODIS AOT observations does not have sufficient information content to constrain aerosol speciation and vertical structure, and the vertical structure of the analysis increments are determined by assumed error covariance.

The simulation of the global aerosol field in GEOS-5, driven by the MERRA atmospheric analyses and assimilating the MODIS-derived AOT is our so-called MERRAero aerosol reanalysis. MERRAero is performed at a horizontal spatial resolution of $0.5^{\circ} \times 0.625^{\circ}$ latitude by longitude and spans the time period from mid-2002 to the present. Applications of MERRAero are described in several recent papers, including Kessner et al. (2013), Buchard et al. (2014, 2015), Colarco et al. (2014b), and Yasunari et al. (2015).

\subsection{Evaluation of the MERRAero Saharan dust plume}

In this section we provide an evaluation of the MERRAerosimulated Saharan dust plume during July 2009 using spacebased satellite imagery and lidar, and ground-based sun photometer observations. For a more comprehensive evaluation of MERRAero, we refer to Buchard et al. (2015). Figure 1 shows a comparison of the simulated monthly mean AOT 
over the Sahara and the tropical North Atlantic Ocean to several satellite-derived AOT products. Observations from MISR (Fig. 1b) provide AOT retrievals at $558 \mathrm{~nm}$ under cloud-free conditions, combining information from nine differently angled push-broom cameras that observe the same scene on Earth over a period of $7 \mathrm{~min}$. Owing to this multiangle viewing geometry, MISR is able to provide retrievals over bright surfaces (Diner et al., 1998; Abdou et al., 2005), with additionally some insight into particle size, shape, and composition. The MISR swath width along the ground is about $360 \mathrm{~km}$, providing global coverage approximately every 9 days. MISR Level 2 AOT values from the latest version of the MISR aerosol retrieval algorithm (v. F12_0022) are used at $558 \mathrm{~nm}$. In addition to MISR, we show the standard Collection 5.1 (Fig. 1c) retrieval from MODIS Aqua at $550 \mathrm{~nm}$, providing near-daily coverage at $10 \mathrm{~km} \times 10 \mathrm{~km}$ spatial resolution. Operationally, MODIS retrieves AOT under cloud-free conditions using reflectances at six visible channels over ocean (Tanré et al., 1997), and over dark land surfaces using two visible and one near-IR channel (Kaufman et al., 1997; Levy et al., 2007a, b). Aerosols are not retrieved over bright desert surfaces in the standard "dark target" land algorithm. We also show the MODIS NNR assimilated in MERRAero (Fig. 1d). For our evaluation, we have regridded all satellite observations to the GEOS-5 grid using a simple box averaging approach.

For a consistent comparison between MISR and GEOS5, we sample our GEOS-5 AOT at the model grid cell that contains the MISR observation at the nearest hourly output time. Compared to MISR, MERRAero captures the general position and AOT magnitude of the observed Saharan dust plume emerging from northern Africa and carried toward the Caribbean. Over the Caribbean, however, the AOT magnitude of the plume is slightly underestimated in MERRAero when compared to MISR, potentially due to cloud contamination in the MISR aerosol retrieval over the ocean (Shi et al., 2014). Over northern Africa, peak AOT values are observed by MISR over Lake Chad and Mali, and these AOT values are greater than what is simulated in MERRAero. For comparison, the standard Collection 5.1 MODIS AOT product (Fig. 1c) shows a much fuller picture of the Saharan aerosol plume, reflecting the greater spatial coverage relative to MISR, except over land. The monthly mean MODIS NNR AOT (Fig. 1d) is most like MERRAero, which is natural as that was the product assimilated. Note that the quality screening of the MODIS data used to compile the NNR AOT results in a lower AOT over the Caribbean than in either the MODIS Collection 5.1 or MISR AOT products.

For a more quantitative evaluation of MERRAero, we compare all AERONET observations of AOT at $550 \mathrm{~nm}$ and AE $(440-870 \mathrm{~nm})$ available in our region of interest $\left(20^{\circ} \mathrm{S}-\right.$ $45^{\circ} \mathrm{N} ; 100^{\circ} \mathrm{W}-60^{\circ} \mathrm{E}$ ) for July 2009 in Fig. 2. AERONET provides measurements of AOT using direct solar extinction measurements at 340,380, 440, 500, 670, 870, and $1020 \mathrm{~nm}$, with $15 \mathrm{~min}$ temporal resolution (Holben et al.,
2001). We use quality-assured and cloud-screened (Level 2) hourly AERONET AOT values (Smirnov et al., 2000) for comparison to MERRAero. AE is a measure of the dependence of AOT on wavelength, which is a function of particle size (Eck et al., 1999) and fine-mode AOT fraction (Schuster et al., 2006). Larger particles like dust typically exhibit AE values less than 1 , while smaller particles have $\mathrm{AE}$ values greater than 1 (Eck et al., 1999). Compared to AERONET, MERRAero AOT is well correlated $\left(r^{2}=0.716\right)$ and has a low bias $(-0.016)$ at 285696 observations during July 2009. MERRAero AE values are slightly less correlated $\left(r^{2}=0.653\right)$ and are biased high $(0.115)$, particularly at low AE values, suggesting that, compared to AERONET, we are simulating aerosols that are too small due to an incorrect representation of the particle size distribution or the incorrect aerosol speciation (e.g., dust vs. smoke).

In Fig. 3, we evaluate the timing and magnitude of MERRAero-simulated AOT and AE by comparing them to several AERONET stations near and downwind of the Saharan source region (station locations in Fig. 1a). Figure 3a compares AOT at $550 \mathrm{~nm}$ and AE $(440-870 \mathrm{~nm})$ values between AERONET hourly observations and corresponding MERRAero values for two stations near the Saharan source region. At Cabo Verde, an island site off the west African coast and under the main dust pathway, MERRAero captures the timing and observed magnitude of AOT during July with a modest correlation coefficient $\left(r^{2}=0.437\right)$. AE values observed by AERONET at Cabo Verde are predominantly less than 1 , indicating the presence of dust aerosols (Fig. 3a). Comparatively, MERRAero AE values are less than 1 and not well correlated $\left(r^{2}=0.209\right)$ when compared to those observed by AERONET, again indicating that we are simulating aerosols that are too small due to an incorrect representation of the dust particle size distribution or too large of a contribution from anthropogenic aerosols, such as biomass burning at this location. On the northern edge of the dust plume, at Santa Cruz, Tenerife, MERRAero is more comparable to the observed AOT magnitude and time series $\left(r^{2}=0.770\right)$, and it accurately captures the passage of several high-AOT events in the latter part of the month (Fig. 3a). Similar to Cabo Verde, both AERONET and MERRAero AE values are predominantly less than $1\left(r^{2}=0.685\right)$, though the model is again biased slightly high throughout the month.

Downwind of the source region (Fig. 3b) at Camaguey, Cuba, MERRAero captures the timing of transported aerosol events $\left(r^{2}=0.589\right)$ but generally simulates lower AOT magnitudes for specific events when compared to AERONET. AERONET and MERRAero AE values at Camaguey are again predominantly less than 1 and anti-correlated with their respective AOT values, properties indicative of Saharan dust transport. When MERRAero values are compared to AERONET AE values, they are only moderately correlated with each other at Camaguey $\left(r^{2}=0.503\right)$ and simulated values are greater than those observed by AERONET. At La Parguera, Puerto Rico, MERRAero accurately simulates the 

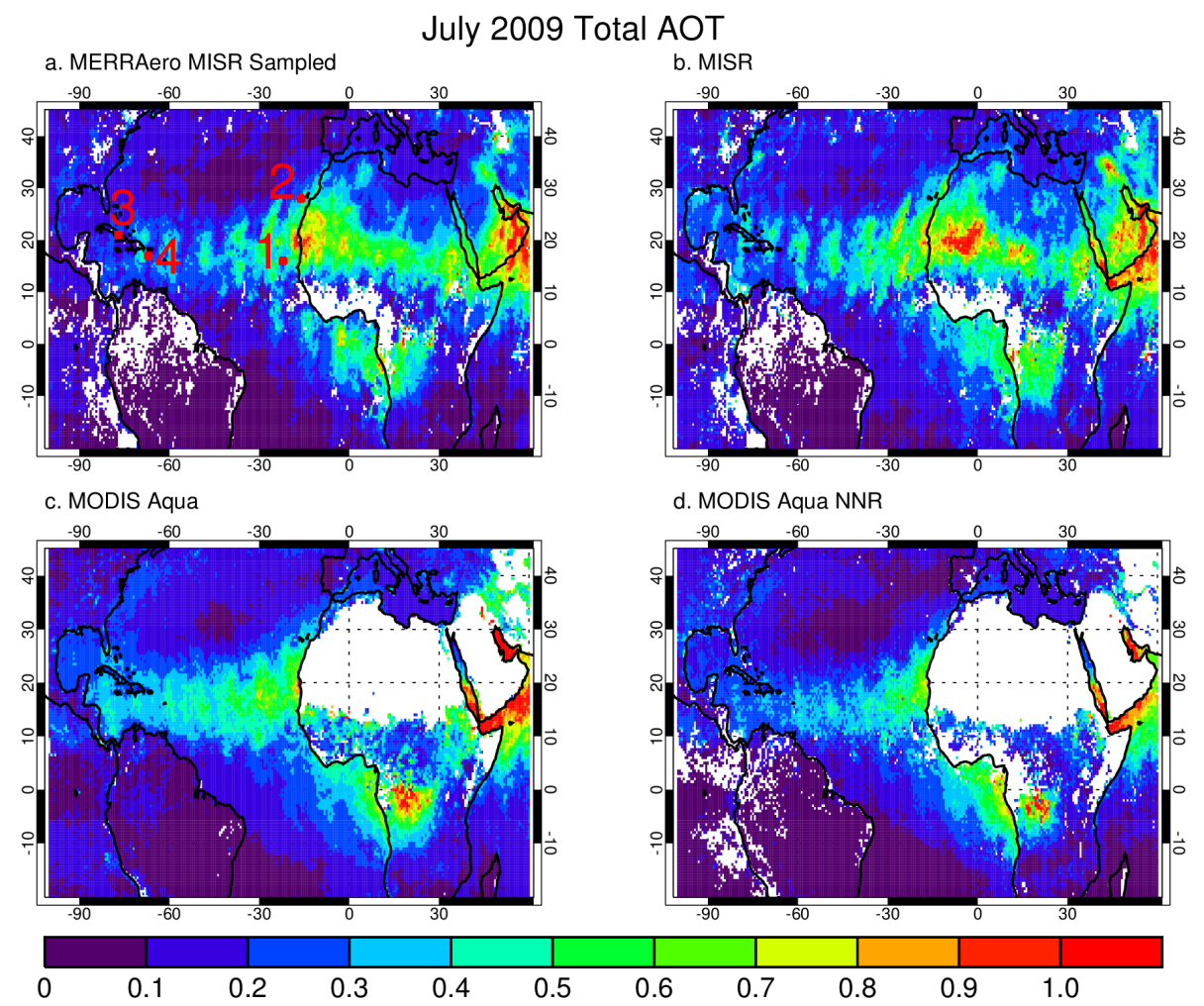

Figure 1. July 2009 AOT for MERRAero sampled along MISR track (a), MISR (b), MODIS Aqua standard retrieval (c), and MODIS Aqua NNR (d) with AERONET locations overlaid (1 - Cabo Verde; 2 - Santa Cruz, Tenerife; 3 - Camaguey; and 4 - La Parguera). White areas correspond to regions where no aerosol retrievals were made.
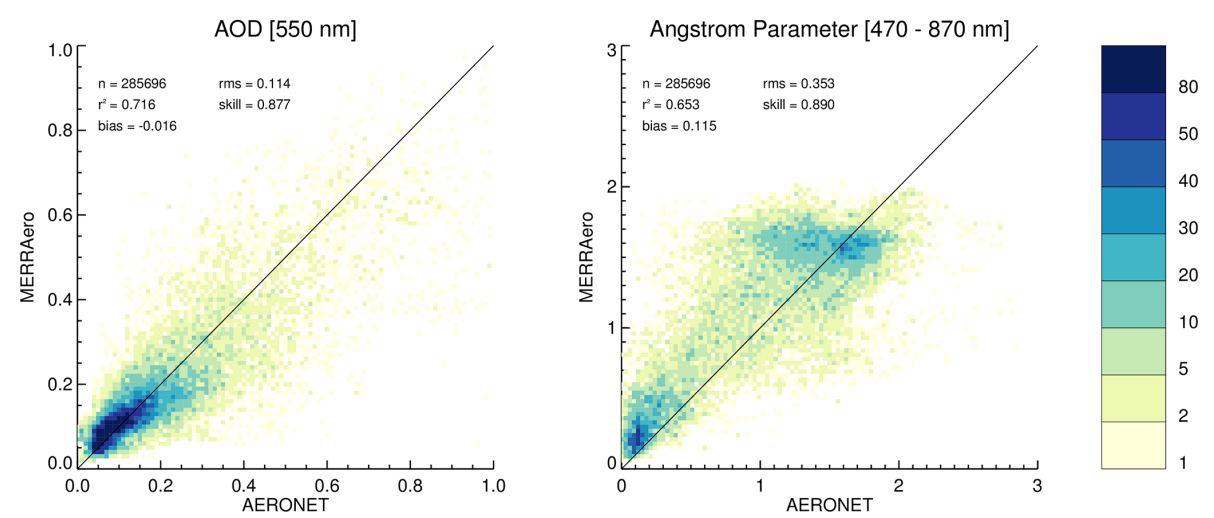

Figure 2. AOT (left) and AE (right) comparisons between MERRAero and AERONET hourly observations $\left(20^{\circ} \mathrm{S}-45^{\circ} \mathrm{N} ; 100^{\circ} \mathrm{W}-60^{\circ} \mathrm{E}\right)$ for July 2009. The number of comparisons at each AERONET station is indicated by the color bar.

timing and magnitude of AOT $\left(r^{2}=0.828\right)$; though consistent with our comparison at Camaguey, MERRAero AE values are slightly biased high when compared to AERONET and are moderately correlated $\left(r^{2}=0.584\right)$.

In Fig. 4 we compare monthly mean MERRAero dust vertical extinction profiles to those determined by CALIOP using the VFM. By using aerosol layers identified as desert dust by the CALIOP VFM, the observed backscatter signal can be converted to extinction using the lidar ratio and the dust ex- tinction may be separated from the total extinction (Winker et al., 2013). In Fig. 4, CALIOP dust extinction data are from their monthly Level 3 gridded $\left(5^{\circ}\right.$ longitude $\times 2^{\circ}$ latitude) product, and the MERRAero dust extinction is sampled along the CALIPSO track and across desert dust features observed by CALIOP at several longitudes moving westward from the Saharan dust source region. Over the source region, at $7.5^{\circ} \mathrm{W}$, MERRAero simulates peak dust extinction values at the same latitudes as observed by CALIOP, but with the 
AERONET and MERRAero AOT/Ångström exponent during July 2009

a. Source Region Sites Cabo Verde
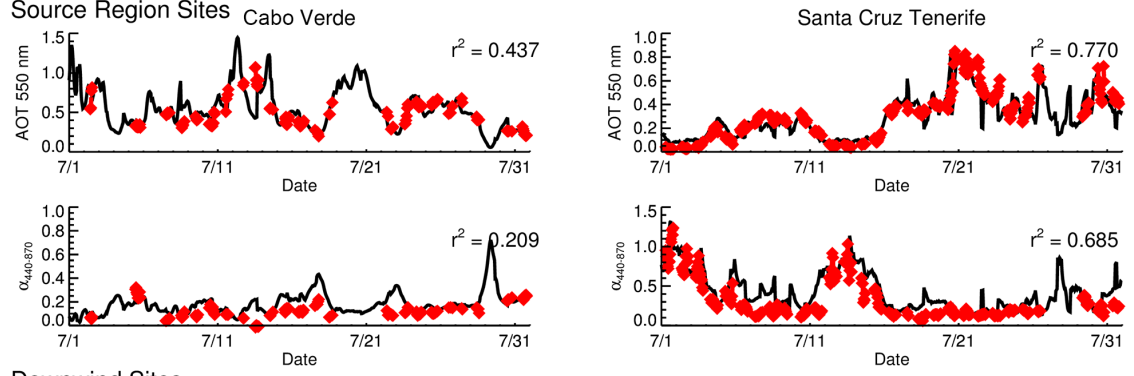

b. Downwind Sites Camaguey
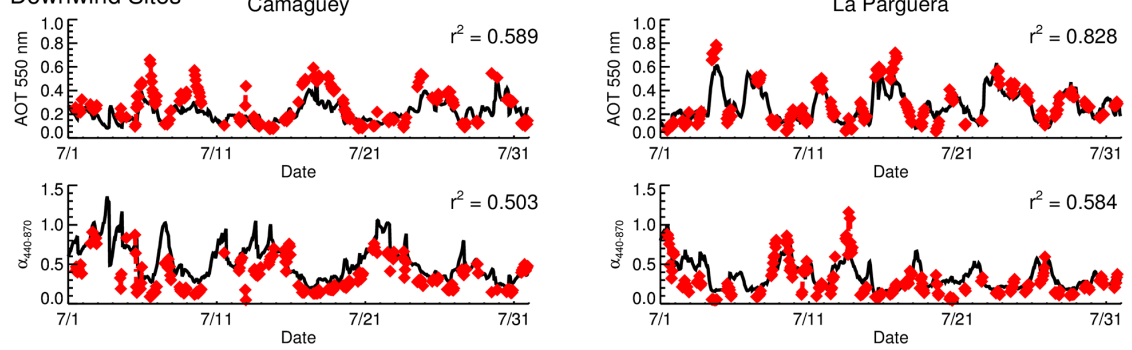

Figure 3. AERONET (red) comparisons to MERRAero (black) AOT and Ångström exponent at sites near the source region (a) and downwind in the Caribbean (b).

\section{July 2009 CALIOP and MERRAero Extinction}

$\stackrel{47.5^{\circ} \mathrm{W}}{\leftarrow} 27.5^{\circ} \mathrm{W} \quad 7.5^{\circ} \mathrm{W}$

CALIOP Dust Extinction $\left(\mathrm{km}^{-1}\right)$
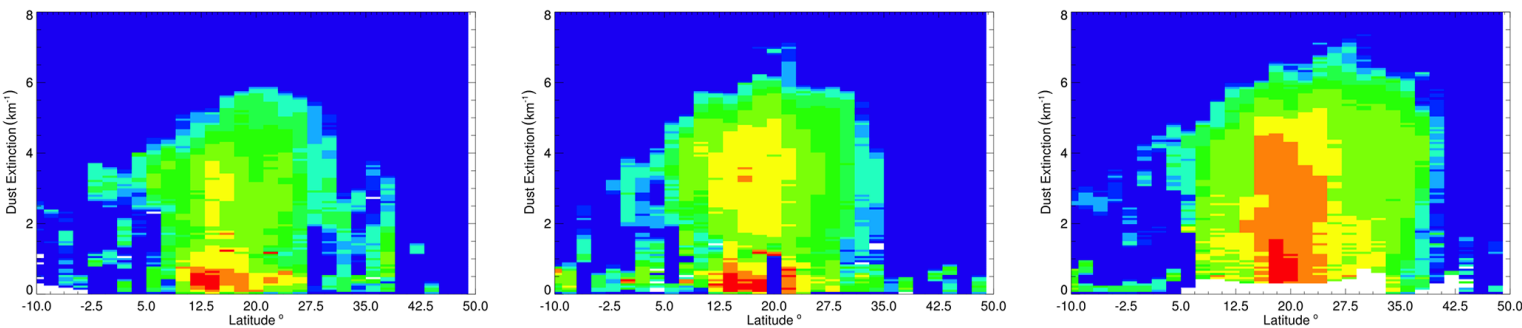

MERRAero Dust and Sea Salt Extinction $\left(\mathrm{km}^{-1}\right)$
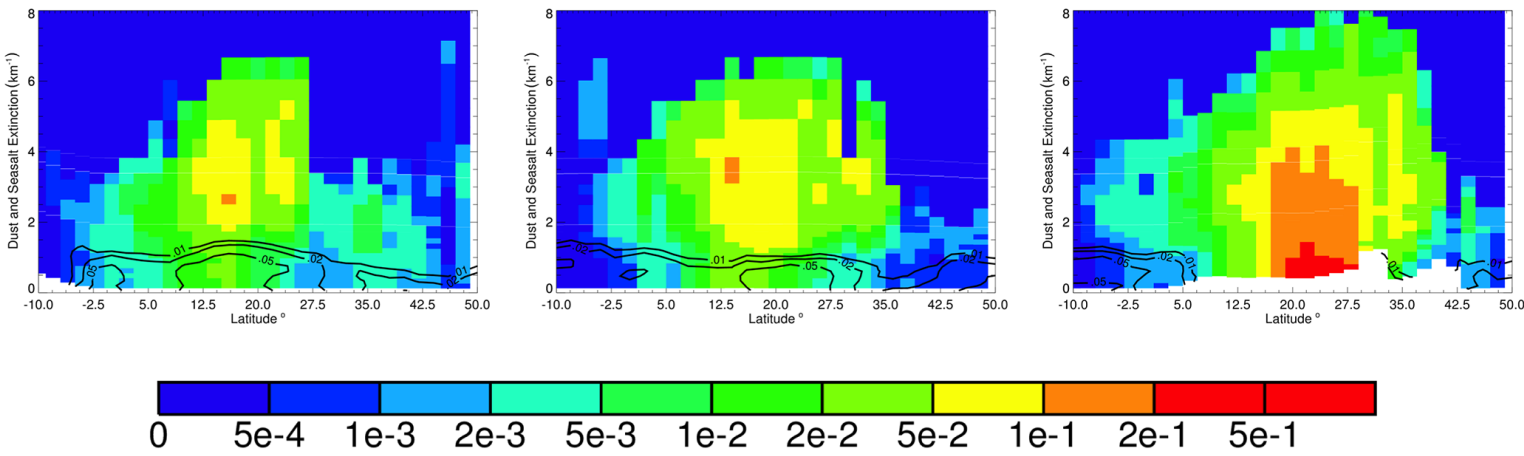

Figure 4. July 2009 CALIOP (top) dust and MERRAero (bottom) dust and sea salt (contour) Level 3 extinction at several north-south slices at longitudes $47.5,27.5$, and $7.5^{\circ} \mathrm{W}$. 
dust confined to lower altitudes and further to the south. We note again that there is no MODIS-derived AOT to assimilate over bright surfaces such as the Saharan source region, which would impact simulated dust plume position and timing, potentially influencing the simulated vertical aerosol distribution when sampled coincident with CALIOP dust features. Moving to the west at $27.5^{\circ} \mathrm{W}$ (in the tropical Atlantic, west of Cabo Verde), MERRAero accurately captures the magnitude of the elevated ( $2-5 \mathrm{~km}$ altitude) dust over the tropical North Atlantic Ocean, though the model does not simulate peak high extinction values below $1 \mathrm{~km}$ and transports slightly more dust both to the north and south when compared to CALIOP. Further to the west at $47.5^{\circ} \mathrm{W}$, MERRAero again captures observed extinction magnitudes and elevation where CALIOP observes dust, but again it transports more dust to the north and south of the observed plume. Once again the high extinction values observed by CALIOP at altitudes below $1 \mathrm{~km}$ are not found in the MERRAero simulation.

Figure 4 shows that MERRAero is able to capture the CALIOP-retrieved elevated dust layers, but not the features seen in CALIOP at low altitudes. The low-level "dust" features seen in the Level 3 CALIOP extinction product highlight the importance of identifying the correct aerosol type in the VFM, as it is central to identifying these features as dust, and hence assigning a dust-appropriate lidar ratio to compute extinction. Recently, Amiridis et al. (2013) found that these low-level dust features result from the CALIOP feature detection and averaging scheme, which tends to exclude non-dust aerosol layers within dust layers if they are located at the same altitude and will classify the entire altitude range as desert or polluted dust. Misidentification of the feature as dust instead of, say, marine could explain these features. Applying the CALIOP-assigned marine lidar ratio $(20 \mathrm{sr})$ instead of what is used for dust $(40 \mathrm{sr})$ would reduce the CALIOP extinction by $50 \%$ for these layers, resulting in extinction values that are comparable to MERRAero. In Fig. 4, we also include the MERRAero sea salt extinction and we see correspondence between low-level MERRAero sea salt and low-level CALIOP dust. However, it is also possible that the model is simply missing the presence of lowaltitude dust layers over the tropical North Atlantic.

\section{Methodology for constructing MERRAero vertical feature masks and application to a case study}

Here we use as an example the CALIOP sampled nighttime aerosol profile (0Z-1Z) across northern Africa on 7 July 2009 (Fig. 5a) to illustrate the CALIOP VFM product and our two synthetic vertical feature masks derived from the MERRAero-simulated aerosol fields. The first of our modelderived VFMs is our MERRAero-CALIOP method, in which we compute the total attenuated backscatter and estimated particulate depolarization ratio (see Eq. 3) profiles based on the MERRAero fields and provide those as inputs to the CALIOP VFM algorithm discussed in Sect. 2.3. Our second model-derived VFM is our MERRAero-Extinction method, in which we map the simulated MERRAero aerosol composition distributions to the types identified by the CALIOP VFM based on the simulated speciated extinction. In practice, our MERRAero-Extinction method is limited in that we are not simulating exactly the aerosol classifications specified in the CALIOP VFM, so this method has some subjectivity associated with it. By constructing two MERRAeroderived VFMs in this manner, we identify two distinct objectives. First, by comparing the MERRAero-CALIOP VFM to the observed CALIOP VFM, we can identify biases in MERRAero aerosol speciation and transport. Then, by comparing our two entirely synthetic MERRAero VFMs, we can document the ability of the CALIOP VFM algorithm to properly identify aerosol types and identify shortcomings of the algorithm itself.

\subsection{Sampling MERRAero}

As mentioned in Sect. 2, the CALIOP feature-finding algorithm looks for enhanced attenuated scattering ratio profiles to differentiate aerosol and cloud features from molecular backscatter. For a given column, up to eight-layer features are permitted in the detection algorithm. For sampling MERRAero along CALIOP aerosol features, we use the $5 \mathrm{~km}$ Level 2 CALIOP layer product, which provides feature vertical thickness and location at $5 \mathrm{~km}$ spatial resolution.

We sample MERRAero at the location of each aerosol feature in the $5 \mathrm{~km}$ Level 2 CALIOP layer product, so there is a direct correspondence between CALIOP aerosol features and the MERRAero model fields that are used to construct the MERRAero-CALIOP and MERRAero-Extinction VFMs. We then regrid all VFMs to the GEOS-5 grid by taking the mode value (VFM flags are qualitative and cannot be averaged; hence the most frequent feature type is used) in the altitude, latitude, and longitude range of a GEOS-5 grid box. As a sensitivity test to our sampling methodologies, we explored the impact of first averaging CALIOP features to the GEOS-5 grid before applying our MERRAero VFM algorithms and found little sensitivity of aerosol typing to aggregation methodology due to the coarse resolution of GEOS-5 when compared to CALIOP.

\subsection{The MERRAero-CALIOP method: application of the CALIOP VFM algorithm to MERRAero}

For our first method, we simulate from the MERRAero aerosol mass fields the profile of $532 \mathrm{~nm}$ total attenuated backscatter, including both the particulate and molecular (Rayleigh) scattering components, and compute the estimated particulate depolarization ratio that is used by the CALIOP VFM algorithm. To reiterate, the $532 \mathrm{~nm}$ particulate total attenuated backscatter is computed by application 
of our aerosol optical properties' look-up tables (Sect. 3.1) to the simulated mass mixing ratios. In order to account for the molecular contribution to our simulated total attenuated backscatter, we follow Russell et al. (1993) to parameterize the Rayleigh backscatter coefficient and molecular optical thickness. We then construct the total attenuated backscatter signal by adding the particulate and molecular backscatter coefficients multiplied by the particulate and molecular twoway transmittances. Because the estimated particulate depolarization ratio and not the actual particulate depolarization ratio is fed into the CALIOP VFM algorithm, we compute the estimated particulate depolarization ratio from our actual particulate depolarization ratio using Eq. (3). We again note that the estimated particulate depolarization ratio is greater than the actual particulate depolarization ratio; however, we find that this has little impact on our aerosol typing in our MERRAero-CALIOP VFM (not shown).

On 7 July 2009 CALIPSO flew southwestward, beginning over Russia, crossing over northeastern Africa, across central Africa, and south to the southwestern corner of Africa (Fig. 5a). In the model we see this track crossing several different aerosol regimes, and the simulated total extinction profile (Fig. 5b) shows several distinct features and plumes of different depths (labeled A, B, and C). The CALIOP total attenuated backscatter and volume depolarization ratio (averaged to $5 \mathrm{~km}$ ) for this case study are shown in Fig. 5e and f, respectively. In Fig. 5c and d, MERRAero total attenuated backscatter and estimated particulate depolarization ratio are shown. Comparing the MERRAero and CALIOP total attenuated backscatter (Fig. 5c and e), we see the MERRAero profile is mostly comparable to CALIOP, showing an aerosol layer from the surface to about $4 \mathrm{~km}$ altitude over eastern Europe and Turkey (Fig. 5b - feature A), followed by an aerosol layer with a top varying in altitude between 2 and $6 \mathrm{~km}$ that corresponds to high AOT over northern Africa (Fig. 5b - feature B), and finally an optically thick aerosol layer over central Africa extending to $4 \mathrm{~km}$ (Fig. $5 \mathrm{~b}$ - feature $\mathrm{C}$ ). Comparing the depolarization ratio profiles along the track (Fig. 5d and f), MERRAero is comparable to CALIOP, showing volume depolarization ratio values ranging from 0.1 to beyond 0.2 over northern Africa (feature B), which is indicative of dust aerosols, although the MERRAero values extend to higher altitudes when compared to CALIOP for this case study. Comparing MERRAero extinction to the estimated depolarization ratio, we see that this bias occurs at altitudes where the dust loading is quite low in the model but is nevertheless above the minimum extinction detection limits of CALIOP $\left(0.003 \mathrm{~km}^{-1}\right.$; Winker et al., 2013), indicating that MERRAero is transporting dust to higher altitudes when compared to CALIOP for this case. The depolarization ratio for the aerosol feature over central Africa is near zero in both CALIOP and MERRAero (feature C), a signature of spherical aerosols such as aged smoke. Looking at the simulated species, we attribute feature $\mathrm{C}$ to biomass burning smoke, which is consistent with the season and geographical location and is borne out in the aerosol typing (see below, Fig. 6).

For each aerosol feature identified in the Level 2 CALIOP layer product, we first require a minimum simulated $532 \mathrm{~nm}$ MERRAero extinction threshold of $0.003 \mathrm{~km}^{-1}$, which corresponds to the CALIOP minimum detectable signal for marine aerosol at night, at $1 \mathrm{~km}$ altitude, and for maximum feature horizontal averaging $(80 \mathrm{~km})$ (Winker et al., 2013). We select marine aerosol for our minimal extinction threshold as it has the smallest lidar ratio; therefore, for a given backscatter in an aerosol layer, marine aerosol will have the lowest corresponding extinction and is thus the most conservative extinction threshold choice. We implement this requirement to prevent flagging MERRAero aerosol layers that would not be detected by CALIOP. If the minimum extinction threshold is not met, the feature will be flagged as clear in the MERRAero-CALIOP VFM.

Next, the MERRAero total attenuated backscatter and estimated particulate depolarization ratios are calculated across the feature altitude using Eqs. (1) and (3), and, along with IGBP surface type and feature altitude, are then fed to the VFM algorithm in Table 1 to assign one of the six CALIOP aerosol types. By applying the CALIOP VFM in this way, there is a direct correspondence between aerosol layers identified by CALIOP and those sampled in MERRAero to construct a comparable VFM.

If CALIOP does not identify an aerosol layer, MERRAero will not be sampled in the model. In this method, MERRAero is only sampled where CALIOP identifies an aerosol feature and, if the aerosol layer exceeds our minimal extinction threshold, one of the six aerosol types in Table 1 will be flagged to construct the MERRAero-CALIOP VFM.

\subsection{The MERRAero-Extinction method: constructing a VFM from MERRAero fields}

As an alternative to the direct simulation of the CALIOP VFM from a MERRAero CALIOP simulator as described above, we have also constructed a VFM that maps the aerosol types explicitly simulated in MERRAero to the aerosol types in the CALIOP VFM. In this way, the MERRAeroExtinction VFM provides a CALIOP-like VFM that is representative of the aerosols simulated in MERRAero. We recall that there are five aerosol types simulated in MERRAero (dust, sea salt, black carbon, organic carbon, and sulfate).

The first step in this MERRAero-Extinction MERRAero classification algorithm is the same as in the MERRAeroCALIOP method, with a threshold extinction of $0.003 \mathrm{~km}^{-1}$. For this algorithm we still sample the model where CALIOP identifies an aerosol feature. For each aerosol feature identified by CALIOP, we compute the extinction of the corresponding layer in MERRAero and check to see if the minimum total extinction threshold requirement is met. As a reminder, MERRAero extinction is determined by converting the simulated aerosol mass mixing ratios of each MERRAero 


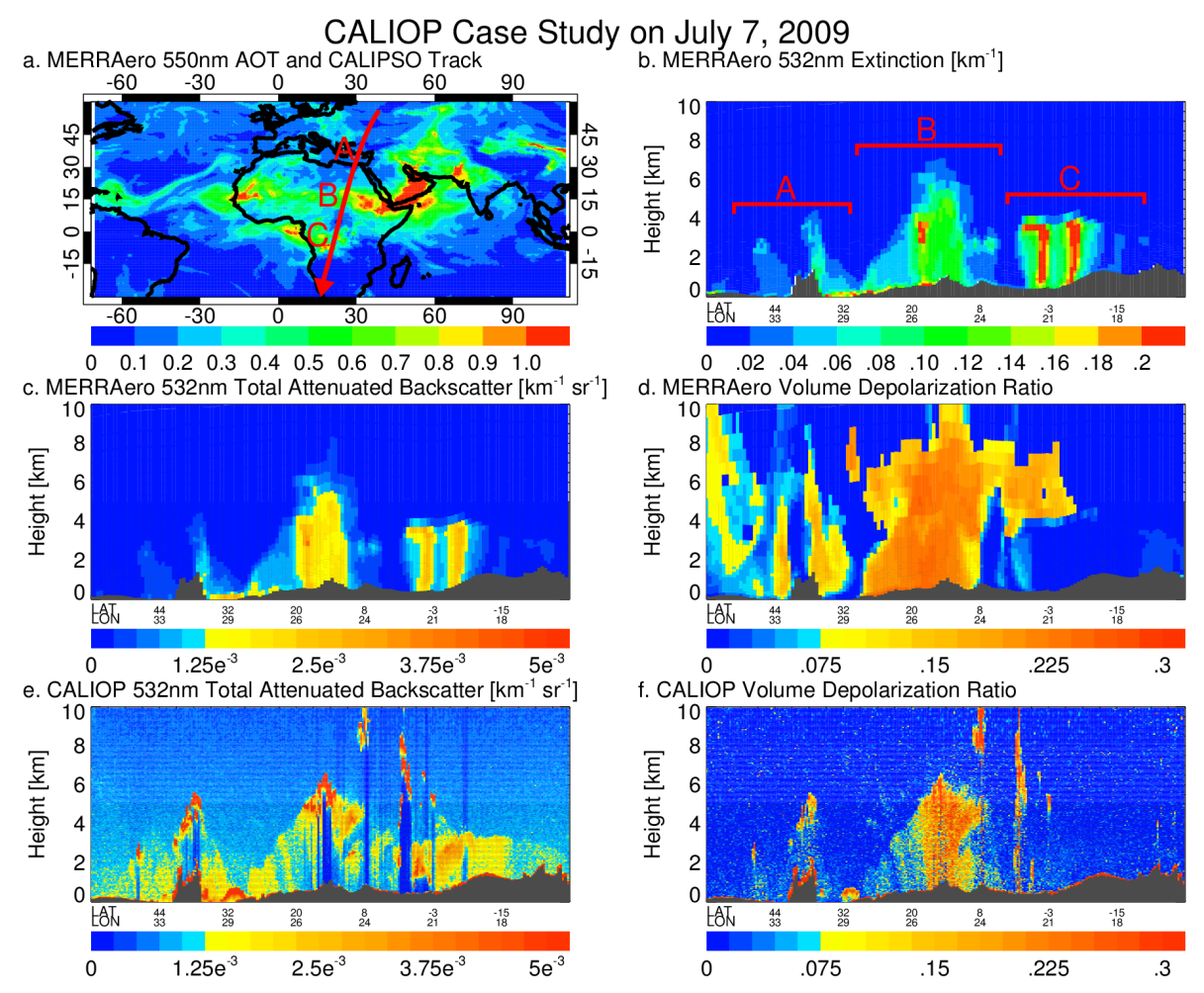

Figure 5. (a) MERRAero $550 \mathrm{~nm}$ total AOT at 00:00 UTC and CALIPSO track from 00:00 to 01:00 UTC over three different aerosol regimes, (b) MERRAero $532 \mathrm{~nm}$ total extinction, (c) MERRAero $532 \mathrm{~nm}$ total attenuated backscatter, (d) MERRAero volume depolarization ratio, (e) CALIOP $532 \mathrm{~nm}$ total attenuated backscatter, and (f) CALIOP volume depolarization ratio on 7 July 2009.

CALIOP and MERRAero VFMs on July 7, 2009

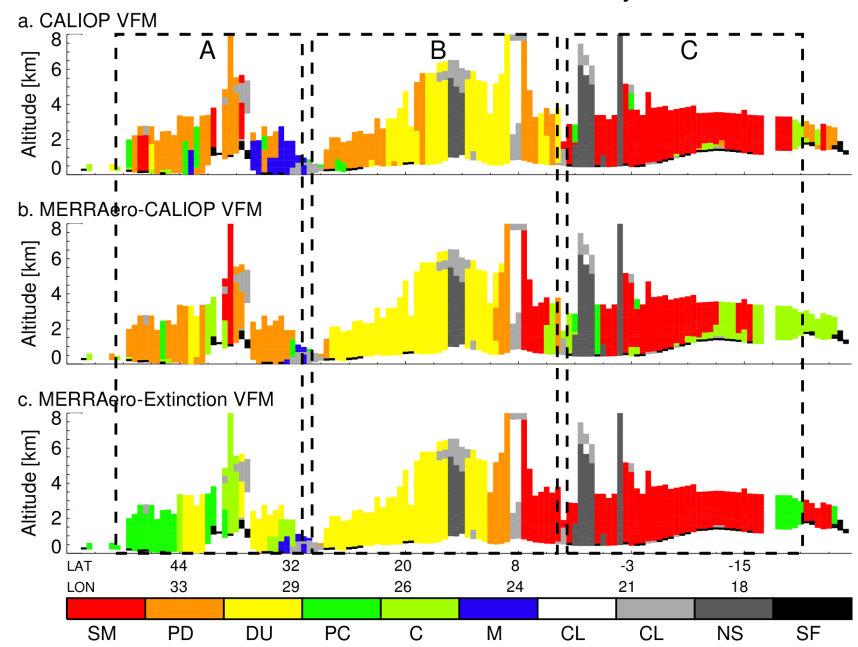

Figure 6. (a) CALIOP VFM, (b) MERRAero-CALIOP VFM, and (c) MERRAero-Extinction on 7 July 2009. Aerosol types include smoke (SM), polluted dust (PD), desert dust (DU), clean continental (C), and marine (M). Regions free of aerosol and clouds are classified as clear. Clouds (CL) and associated signal attenuation (NS), as well as the surface (SF), are also shown. aerosol type (dust, sea salt, sulfate, black and organic carbon) to extinction using look-up tables of mass extinction efficiencies for each aerosol type (Sect. 3.1). This method should be distinguished from the CALIOP method of converting the backscatter to extinction via the lidar ratio.

If our threshold requirement is met, we determine the individual extinction for each of the simulated aerosol types over the feature altitude range. For simplicity of type assignment we aggregate the black and organic carbon together to be a single carbonaceous species, which is practically used to assign aerosol types to the CALIOP "smoke" classification (see below, and Table 2). Because we consider four independent aerosol types in MERRAero, we consider the presence of a specific aerosol to be significant if it contributes at least $25 \%$ of the total extinction across a feature. For example, if the total extinction across a feature is greater than $0.003 \mathrm{~km}^{-1}$ and dust and carbon each contribute $>25 \%$ to the feature signal, then both dust and carbon are flagged as being present. In our MERRAero-Extinction method, it is possible that extinction values will not meet threshold criteria, and so our aerosol typing can be flagged as clear even where CALIOP has identified a layer.

A major challenge in constructing a VFM using MERRAero fields lies in relating the aerosol types simulated by the model to the aerosol types provided by the CALIOP 
Table 2. Mapping of MERRAero aerosol mixtures to CALIOP VFM flags.

\begin{tabular}{lll}
\hline $\begin{array}{l}\text { CALIPSO and MERRAero } \\
\text { aerosol VFM types }\end{array}$ & $\begin{array}{l}\text { MERRAero-Extinction } \\
\text { aerosol mixtures }\end{array}$ & $\begin{array}{l}\text { MERRAero-Extinction minimum aerosol } \\
\text { fractions for typing }\end{array}$ \\
\hline No signal or cloud & N/A & N/A \\
\hline Marine (M) & Sea salt & $\mathrm{F}_{\mathrm{ss}} \geq 0.75$ \\
\hline Desert dust (DU) & Dust & $\mathrm{F}_{\mathrm{du}} \geq 0.75$ \\
\hline Polluted continental (PC) & Sulfate + carbon & $\mathrm{F}_{\mathrm{su}}, \mathrm{F}_{c} \geq 0.25, \mathrm{~F}_{\mathrm{su}}+\mathrm{F}_{c} \geq 0.75$ \\
\hline Clean continental $(\mathrm{C})$ & Sulfate & $\mathrm{F}_{\mathrm{su}} \geq 0.75$ \\
\hline Polluted dust (PD) & Dust + sulfate & $\mathrm{F}_{\mathrm{du}}, \mathrm{F}_{\mathrm{su}} \geq 0.25, \mathrm{~F}_{\mathrm{du}}+\mathrm{F}_{\mathrm{su}} \geq 0.75$ \\
& Dust + carbon & $\mathrm{F}_{\mathrm{du}}, \mathrm{F}_{c} \geq 0.25, \mathrm{~F}_{\mathrm{du}}+\mathrm{F}_{c} \geq 0.75$ \\
& Dust + sulfate + carbon & $\mathrm{F}_{\mathrm{du}}, \mathrm{F}_{\mathrm{su}}, \mathrm{F}_{c} \geq 0.25, \mathrm{~F}_{\mathrm{du}}+\mathrm{F}_{\mathrm{su}}+\mathrm{F}_{c} \geq 0.75$ \\
& Dust + sea salt & $\mathrm{F}_{\mathrm{du}}, \mathrm{F}_{\mathrm{ss}} \geq 0.25, \mathrm{~F}_{\mathrm{du}}+\mathrm{F}_{\mathrm{ss}} \geq 0.75$ \\
& Dust + sulfate + sea salt & $\mathrm{F}_{\mathrm{du}}, \mathrm{F}_{\mathrm{su}}, \mathrm{F}_{\mathrm{ss}} \geq 0.25, \mathrm{~F}_{\mathrm{du}}+\mathrm{F}_{\mathrm{su}}+\mathrm{F}_{\mathrm{ss}} \geq 0.75$ \\
& Dust + carbon + sea salt & $\mathrm{F}_{\mathrm{du}}, \mathrm{F}_{c}, \mathrm{~F}_{\mathrm{ss}} \geq 0.25, \mathrm{~F}_{\mathrm{du}}+\mathrm{F}_{c}+\mathrm{F}_{\mathrm{ss}} \geq 0.75$ \\
\hline Smoke (SM) & Carbon & $\mathrm{F}_{c} \geq 0.75$ \\
\hline N/A & Sea salt + carbon & $\mathrm{F}_{\mathrm{ss}}, \mathrm{F}_{c} \geq 0.25, \mathrm{~F}_{\mathrm{ss}}+\mathrm{F}_{c} \geq 0.75$ \\
& Sea salt + sulfate & $\mathrm{F}_{\mathrm{ss}}, \mathrm{F}_{\mathrm{su}} \geq 0.25, \mathrm{~F}_{\mathrm{ss}}+\mathrm{F}_{\mathrm{su}} \geq 0.75$ \\
\hline
\end{tabular}

VFM, as we do not explicitly simulate the mixtures of aerosols that are flagged by the CALIOP VFM (e.g., polluted dust). Our mapping to the CALIOP VFM aerosol types and the minimal fraction of each MERRAero aerosol type for each CALIOP aerosol type is laid out in Table 2. Some of the MERRAero to CALIOP VFM mapping is straightforward, such as desert dust, but in other cases - specifically those related to polluted aerosol types - the typing criteria are more subjective. For example, in grid cells where dust, sea salt, or sulfate aerosol meet the total extinction threshold and are the only aerosol types to contribute at least $25 \%$ to the total extinction signal, these cells are mapped directly to the desert dust, marine, or clean continental CALIOP VFM flags, respectively. The CALIOP Algorithm Theoretical Basis Document (ATBD) (Liu et al., 2005) indicates that the polluted continental flag could be representative of a sooty sulfate aerosol. Therefore, we map our MERRAero carbon + sulfate mixtures to the polluted continental CALIOP VFM flag. Similarly, the CALIOP algorithm indicates that the polluted dust flag is representative of a dust + smoke or a dust + sulfate mixture. In practice, CALIOP identifies any dust + other aerosol mixture as polluted dust (Omar et al., 2009). Therefore, to be consistent with CALIOP, any feature where dust and another aerosol species each contribute to at least $25 \%$ of the total extinction is mapped to polluted dust. For our aforementioned hypothetical feature that meets the extinction threshold criteria and for which both dust and carbon contribute each to $>25 \%$ of the extinction signal, the feature would be identified as polluted dust using the MERRAero-Extinction method (Table 2).
In Table 3 we compare $532 \mathrm{~nm}$ lidar ratios $\left(S_{a}\right)$ and SSA from our average MERRAero-Extinction mapping of MERRAero aerosols to CALIOP aerosol types to CALIOP values derived by applying Mie theory directly to the physical and optical properties of the CALIOP aerosol models for July 2009 (Table 1 from Omar et al., 2009). We note that our methodology differs slightly from Omar et al. (2009) as the discrete-dipole approximation was used to determine the optical properties for CALIOP dust particles; however, our MERRAero lidar ratio for desert dust is comparable to the value used in the VFM algorithm (Omar et al., 2009). While both the MERRAero and CALIOP lidar ratios for desert dust are lower than those observed for Saharan dust by surface measurements (Tesche et al., 2009; Amiridis et al., 2013; Kanitz et al., 2014), desert dust and polluted dust layers are classified using the estimated particulate depolarization ratio in the CALIOP VFM algorithm. Therefore, our classification of dusty layers is not sensitive to our underestimation of the desert dust lidar ratio for Saharan dust. We note that, if the lidar ratio were used to derive extinction instead of using our look-up table approach combined with the assimilation of MODIS AOT in MERRAero, our desert dust extinction would be underestimated, as was shown for CALIOP (Wandinger et al., 2010; Schuster et al., 2012). Comparing the MERRAero and CALIOP $S_{a}$ and SSA values for other aerosol types, there are notable differences in the clean continental and polluted dust $S_{a}$, as well as the polluted dust SSA. While MERRAero and CALIOP $S_{a}$ and SSA values are sensitive to assumed physical and optical properties, their differences also highlight the challenge of mapping MERRAero aerosols to the CALIOP aerosol types. The higher MER- 
RAero clean continental $S_{a}$ value is the result of mapping MERRAero sulfate aerosols to the background clean continental CALIOP aerosol type. Similarly, by mapping any dust mixture to the polluted dust type, our polluted dust $S_{a}$ and SSA values also include dust mixtures with highly scattering aerosols such as sea salt that result in a lower $S_{a}$ and higher SSA when compared to the CALIOP polluted dust model. Overall, however, there is good agreement between MERRAero and CALIOP $S_{a}$ and SSA values, indicating that our MERRAero-Extinction methodology leads to an adequate representation of the CALIOP aerosol types.

\subsection{A VFM vase study on 7 July 2009}

Figure 6 shows the CALIOP and two MERRAero VFMs for the orbital track shown in Fig. 5a on 7 July 2009. Here, the CALIOP VFM identified a layer of polluted dust over Turkey (feature A in Fig. 5a), primarily located between 2 and $5 \mathrm{~km}$ in altitude, followed by a low layer of marine aerosol over the Mediterranean Sea (Fig. 6a). Moving south over northern Africa, polluted dust is detected by the CALIOP VFM at altitudes below $2-3 \mathrm{~km}$ near the coastline, transitioning to desert dust near $23^{\circ} \mathrm{N}$ at altitudes to $3-5 \mathrm{~km}$ and extending south to $8^{\circ} \mathrm{N}$ over northern Africa (Fig. 5a - feature B). South of $8^{\circ} \mathrm{N}$, the CALIOP VFM transitions from desert dust to polluted dust, as this is a region where Saharan dust aerosols frequently interact with smoke aerosols from biomass burning to the south. Continuing south of $5^{\circ} \mathrm{N}$ over central Africa (Fig. 5a - feature C), smoke aerosols are the dominant aerosol type in the CALIOP VFM (Fig. 6a).

By comparing the CALIOP VFM (Fig. 6a) to our MERRAero-CALIOP VFM (Fig. 6b), we can identify biases in simulated aerosol speciation and transport in MERRAero by identifying instances where the CALIOP and the MERRAero-CALIOP method aerosol typing differ. Over Turkey, the MERRAero-CALIOP method flags a mixture of polluted dust, desert dust, and smoke as the dominant aerosol types and compares well with CALIOP. However, over the Mediterranean Sea, our MERRAero-CALIOP VFM is predominantly polluted dust vs. marine, suggesting that MERRAero is transporting dust into a region that was observed to be relatively dust free by CALIOP. Our MERRAeroCALIOP VFM (Fig. 6b) does not capture this transition and instead flags desert dust as the predominant aerosol type over northern Africa. Additionally, the observed transition of polluted dust to smoke in the CALIOP VFM occurs further to the north in the MERRAero-CALIOP VFM, suggesting that MERRAero is not simulating dust as far south as observed by CALIOP. South of $5^{\circ} \mathrm{N}$, our MERRAero-CALIOP VFM flags smoke and is comparable to the CALIOP VFM to $10^{\circ} \mathrm{S}$, but it then transitions to background continental aerosol.

By comparing our MERRAero-CALIOP (Fig. 6b) and MERRAero-Extinction (Fig. 6c) VFMs, we can assess the CALIOP VFM algorithm for this case. Over Turkey, our MERRAero-CALIOP and MERRAero-Extinction VFMs differ: the MERRAero-Extinction VFM shows less dust and a greater presence of polluted continental aerosols than the MERRAero-CALIOP VFM. This highlights the challenge of classifying aerosol mixtures when there are not any preeminent properties of the aerosol feature used to determine aerosol type. Here, there was enough dust in MERRAero to classify the aerosol layer as polluted dust in terms of the estimated particulate depolarization ratio in the MERRAeroCALIOP VFM, but in terms of extinction the typing threshold to identify polluted dust was not met, resulting in an identification of polluted continental (smoke + sulfate) aerosols. In this case, the CALIOP VFM algorithm threshold may be too permissive for classifying aerosol features with low estimated particulate depolarization ratios (i.e., polluted dust), or it is possible that the model thresholds in our MERRAeroExtinction VFM are too conservative. Over the Mediterranean Sea (between features A and B), our MERRAeroCALIOP and MERRAero-Extinction VFMs agree in terms of not flagging as much marine aerosol as observed by CALIOP but differ in terms of type: our MERRAeroExtinction VFM indicates a transition of dust to continental aerosol, while our MERRAero-CALIOP VFM is dominated by polluted dust. South of the Mediterranean Sea, our MERRAero VFMs agree with one another and match the transition of desert dust over northern Africa to polluted dust over the Sahel, followed by smoke over central Africa.

In this case study, we have demonstrated the utility of constructing two different VFMs for identifying biases in simulated MERRAero vertical aerosol distributions by comparing our MERRAero-CALIOP VFM to the CALIOP VFM, as well as establishing limitations of the CALIOP VFM algorithm by comparing our MERRAero-CALIOP and MERRAero-Extinction VFMs. In the next section, we extend our analysis to include all of July 2009 to quantify biases in MERRAero vertical aerosol distributions and optical properties, as well as the CALIOP VFM algorithm on a longer timescale.

\section{Monthly application of VFM for July 2009}

In this section, we extend our evaluation of the vertical aerosol distributions in our MERRAero aerosol reanalysis by applying both of our MERRAero VFM methodologies for comparison to the CALIOP VFM for July 2009. For our monthly analysis, we perform our sampling of MERRAero as described in Sect. 4.1 and bin all CALIOP and MERRAero VFMs on the $0.5^{\circ} \times 0.625^{\circ}$ MERRAero grid. Due to the narrow swath of the CALIOP instrument, many grid boxes on the model's grid are devoid of observations at the monthly timescale. Therefore, in order to produce maps relatively devoid of observational gaps, we regrid the CALIOP and MERRAero VFMs to a coarser $1^{\circ} \times 1.25^{\circ}$ spatial resolution, maintaining the most frequent type classification as the grid box value. After this regridding, the number of observa- 
Table 3. MERRAero-Extinction and Mie theory computed CALIOP 532 lidar ratio $\left(S_{a}\right)$ and single-scattering albedo (SSA) for each VFM aerosol type.

\begin{tabular}{lllll}
\hline CALIPSO and MERRAero & MERRAero & Computed CALIOP & MERRAero & Computed CALIOP \\
Aerosol VFM types & $532 \mathrm{~nm} S_{a}[\mathrm{sr}]$ & $532 \mathrm{~nm} S_{a}$ [sr] & $532 \mathrm{~nm} \mathrm{SSA}$ & 532 nm SSA \\
\hline Marine (M) & 32 & 25 & 0.98 & 0.99 \\
Desert dust (DU) & 46 & 40 & 0.92 & 0.92 \\
Polluted continental (PC) & 61 & 69 & 0.89 & 0.93 \\
Clean continental (C) & 63 & 34 & 0.92 & 0.90 \\
Polluted dust (PD) & 49 & 60 & 0.92 & 0.85 \\
Smoke (SM) & 59 & 75 & 0.86 & 0.83 \\
\hline
\end{tabular}

tions within each grid box during a month becomes more uniform, with most tropical grid boxes containing four to eight observations at each altitude bin. Within each grid box, we find the mode and determine the fraction of occurrence of VFM type to understand the variability of aerosol type during the month. In an effort to avoid cloud attenuation impacts on layer identification, we only consider cloud-free VFM profiles that contain aerosols for our monthly analysis. Additionally, for our monthly analysis we combine both CALIOP day and night VFM files, as we did not see a significant impact on VFM typing and sampling when they were treated separately (not shown).

Figure 7 shows the July 2009 CALIOP VFM at $1 \mathrm{~km}$ vertical intervals over northern Africa, the tropical North Atlantic, and the Caribbean. At $0-1 \mathrm{~km}$, the CALIOP VFM is dominated by desert dust over most of northern Africa. Downwind of the source region, we see a mixture of marine and polluted dust extending into the Caribbean between 10 and $20^{\circ} \mathrm{N}$. In the Caribbean, we see a frequent occurrence of polluted dust, which extends over into the eastern Pacific. Moving up to 1-2 km, northern Africa is again dominated by desert dust and we see a greater fraction of polluted dust vs. marine aerosol downwind of the source region associated with dust transport as part of the lofted Saharan air layer (SAL). Over the Caribbean and eastern Pacific, we again see a mixture of polluted dust and marine aerosol. At $2-3$ and $3-4 \mathrm{~km}$, northern Africa remains dominated by desert dust, and we see an increased fraction of polluted and desert dust with altitude both downwind of the source region and over the Caribbean/eastern Pacific associated with dust-laden SAL transport. We also begin to see more regions where the grid cells are identified as clear in the CALIOP VFM, where no aerosol layers were detected throughout the month. Continuing upward to 4-5 and 5-6 km, aerosol layers are less common, but we continue to see desert dust over northern Africa and a large fraction of desert and polluted dust downwind over the tropical North Atlantic. However, over the Caribbean, while both desert and polluted dust flags are present, there are relatively fewer grid boxes that contain dust aerosols at 5-6 km when compared to the tropical North
Atlantic and northern Africa, related to dust removal during transport from the Saharan source region to the Caribbean.

Figure 7 also shows the July 2009 MERRAero-CALIOP VFM. To reiterate, by comparing the MERRAero-CALIOP VFM to the CALIOP VFM, we can assess biases in our simulated dust transport. Over the Saharan source region, the MERRAero-CALIOP VFM flags desert dust over central northern Africa and is in agreement with the CALIOP VFM at all altitude ranges. Over the tropical North Atlantic Ocean at $0-1 \mathrm{~km}$, the MERRAero-CALIOP VFM flags a mixture of desert and polluted dust and is comparable to the CALIOP VFM. However, at $1-2 \mathrm{~km}$ and above, the MERRAero-CALIOP VFM flags a broader dust plume that extends significantly farther north and south when compared to the CALIOP VFM, suggesting that dust transport is too liberal in MERRAero. Additionally, on the periphery of the transported Saharan dust plume, the MERRAero-CALIOP VFM flags significantly more aerosol layers as polluted dust in the transition from desert dust to marine aerosol, which is not seen in the CALIOP VFM. We recall that in MERRAero the fraction of each individual aerosol species does not change when MODIS AOT is assimilated. Therefore, if the fraction of dust relative to other aerosol species is incorrect, this bias will be preserved after MODIS AOT is assimilated. Over the Caribbean and eastern Pacific Ocean, the CALIOP and MERRAero-CALIOP VFMs are comparable at $0-1 \mathrm{~km}$, flagging a mixture of desert dust, polluted dust, and marine aerosol. Above $1 \mathrm{~km}$, our MERRAero-CALIOP VFM flags a greater presence of desert dust and polluted dust when compared to the CALIOP VFM. This difference persists into the eastern Pacific, suggesting that, in addition to simulating a much broader Saharan dust plume, MERRAero transports dust too far west when compared to CALIOP.

Finally, the July 2009 MERRAero-Extinction VFM is also shown in Fig. 7. By comparing our MERRAero-Extinction and MERRAero-CALIOP VFMs, we can assess the performance of the CALIOP VFM algorithm. Over the Saharan source region, both of our MERRAero VFMs are in agreement and flag desert dust as the dominant aerosol type. Over the tropical North Atlantic at $0-1,1-2$, and $2-3 \mathrm{~km}$, the MERRAero-Extinction VFM flags a narrower plume 


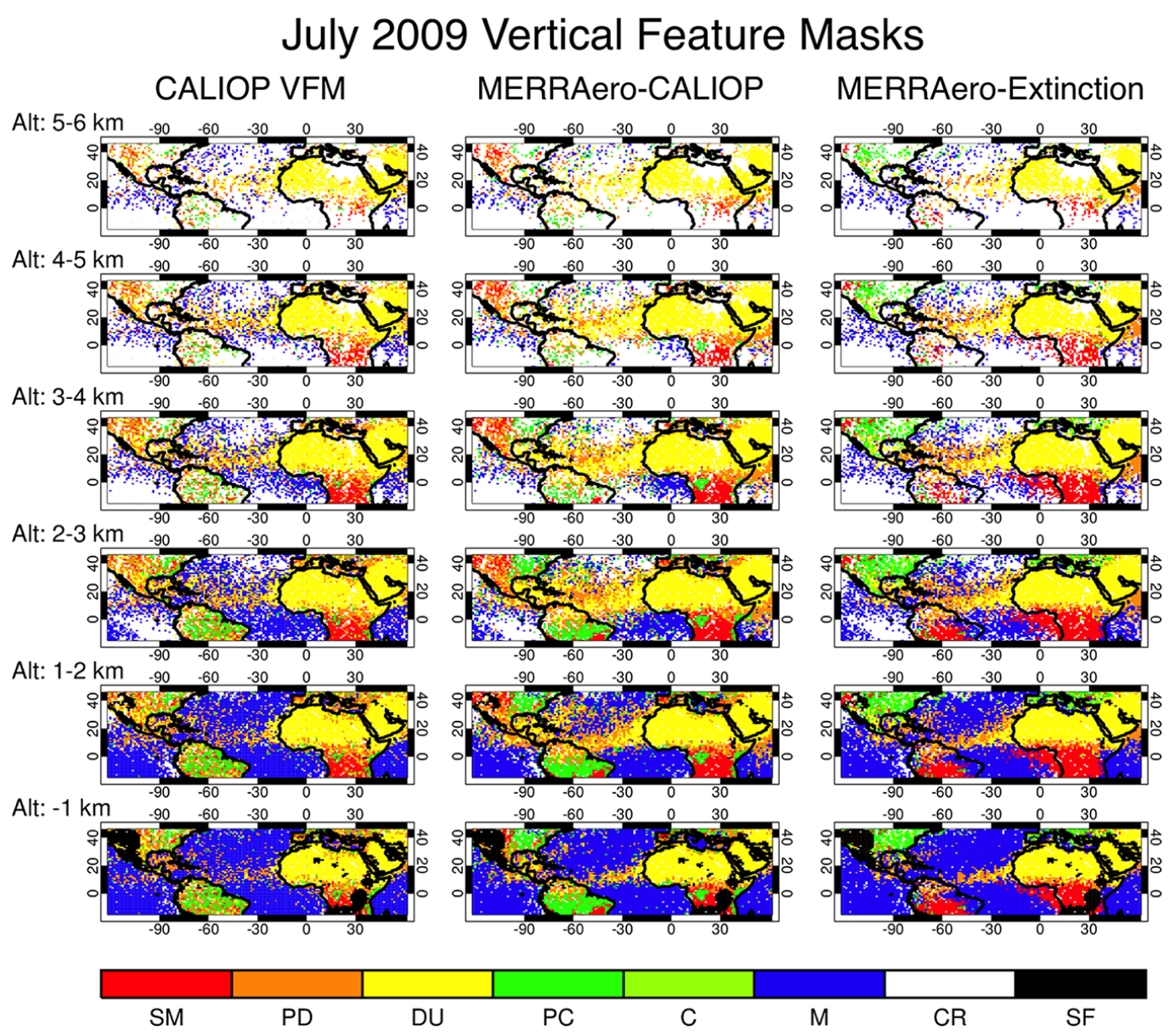

Figure 7. (a-f) CALIOP (left), MERRAero-CALIOP (center), and MERRAero-Extinction (right) VFMs at $1 \mathrm{~km}$ intervals for July 2009. Aerosol types include smoke (SM), polluted dust (PD), desert dust (DU), clean continental (C), and marine (M). The surface (SF) and regions with no data (ND) are also shown.

of desert dust surrounded by polluted dust (dust + sea salt) that compares more favorably to the CALIOP VFM than our MERRAero-CALIOP VFM. Comparing our MERRAero VFMs, we see that the MERRAero-CALIOP VFM dust plume is broader than the MERRAero-Extinction VFM over the tropical North Atlantic, suggesting that using the estimated particulate depolarization ratio alone in the CALIOP VFM algorithm potentially flags aerosol layers as dusty when the actual dust aerosol loading is small. Above $3 \mathrm{~km}$, the MERRAero-CALIOP VFM continues to flag a broad region of desert dust and polluted dust aerosol, while the MERRAero-Extinction VFM aerosol flags are very comparable to CALIOP. Over the Caribbean and eastern Pacific, our MERRAero-Extinction VFM slightly differs from the MERRAero-CALIOP and CALIOP VFMs and flags more marine aerosol pixels at the expense of desert and polluted dust. At $1-2 \mathrm{~km}$, our MERRAero-CALIOP VFM is dominated by desert and polluted dust, while our MERRAeroExtinction VFM flags a mixture of desert dust, polluted dust, and marine aerosol. At $3 \mathrm{~km}$ and beyond, our MERRAero-
Extinction VFM flags fewer dusty aerosol layers with altitude, while our MERRAero-CALIOP VFM continues to flag desert dust and polluted dust over the Caribbean and eastern Pacific. This feature again suggests that using the estimated particulate depolarization ratio alone is too permissive for flagging dust layers in the CALIOP VFM algorithm, particularly in regions where the dust aerosol loading is low and multiple aerosol types are present.

We note that Fig. 7 shows the mode aerosol types for July 2009, as VFM flags are not quantitative and cannot be averaged. Therefore, in Fig. 8, we show the fraction of occurrence for each VFM flag over the tropical North Atlantic $\left(0-30^{\circ} \mathrm{N}, 60-15^{\circ} \mathrm{W}\right.$, Fig. $\left.8 \mathrm{a}\right)$ and the Caribbean/eastern Pacific $\left(0-30^{\circ} \mathrm{N}, 110-60^{\circ} \mathrm{W}\right.$, Fig. $\left.8 \mathrm{~b}\right)$. Over the tropical North Atlantic, we again see that the our MERRAero-CALIOP VFM flags a significantly greater occurrence of desert dust and polluted dust at the expense of marine aerosol layers when compared to the CALIOP VFM, reaffirming that a greater fraction of dust is being transported downwind in MERRAero. Our MERRAero-Extinction VFM is com- 
a. VFM Fraction of Occurrence over Tropical North Atlantic $0-30^{\circ} \mathrm{N}, 60^{\circ} \mathrm{W}-15^{\circ} \mathrm{W}$
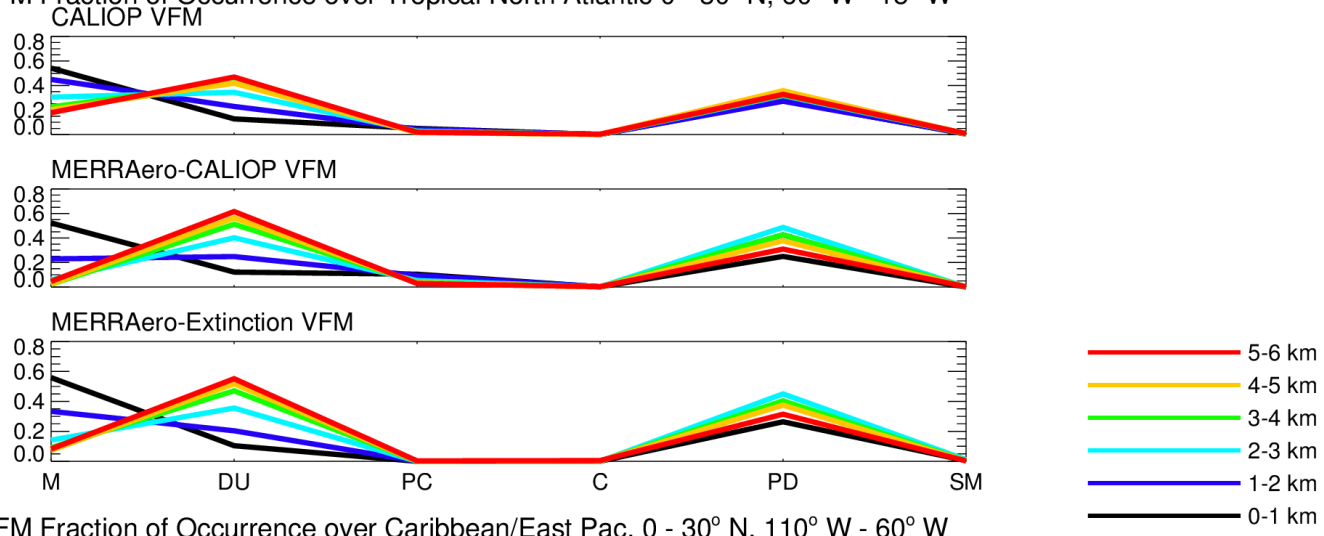

b. VFM Fraction of Occurrence over Caribbean/East Pac. $0-30^{\circ} \mathrm{N}, 110^{\circ} \mathrm{W}-60^{\circ} \mathrm{W}$
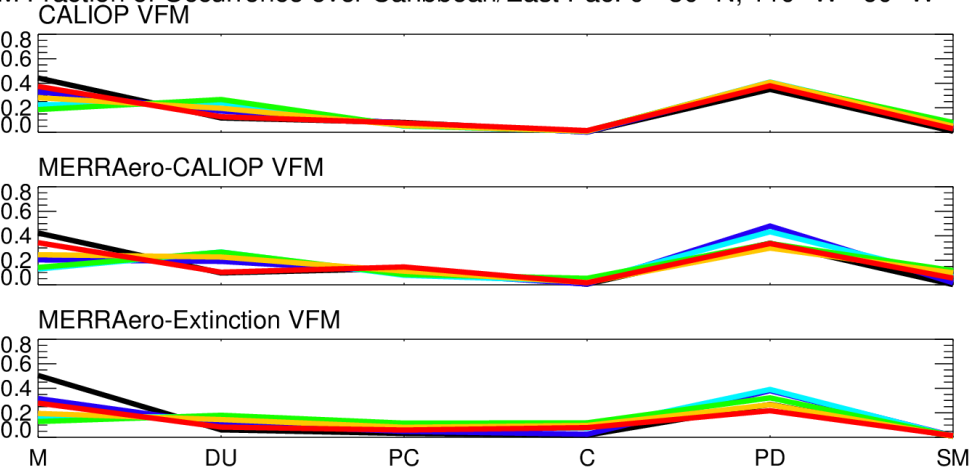

Figure 8. VFM fraction of occurrence over the tropical North Atlantic (a) and Caribbean/eastern Pacific (b). Aerosol types include marine (M), desert dust (DU), polluted continental (PC), clean continental (C), polluted dust (PD), and smoke (SM).

parable to the CALIOP VFM over the tropical North Atlantic; however, when we compare our MERRAero-CALIOP and MERRAero-Extinction VFMs, we clearly see that the CALIOP VFM algorithm flags a greater occurrence of desert and polluted dust in regions that are not identified as dusty in our MERRAero-Extinction VFM. These features persist over the Caribbean/eastern Pacific; we again see a greater occurrence of desert dust and polluted dust at the expense of marine aerosol in our MERRAero-CALIOP VFM when compared to the CALIOP and MERRAero-Extinction VFMs.

\section{Conclusions}

In this study, we have explored the utility of the CALIOP VFM for evaluating Saharan dust transport for July 2009 in the NASA GEOS-5 aerosol reanalysis (MERRAero). The CALIOP VFM is particularly used for evaluating global aerosol transport models, as the VFM provides information regarding vertical location and aerosol type, which is challenging to assess using traditional column measurements of AOT such as MODIS.

For our analysis, we first evaluated Saharan dust in our $0.5^{\circ} \times 0.625^{\circ}$ MERRAero simulation for July 2009 . Compared to column AOT observations from MISR, MODIS Aqua, and AERONET, we showed that MERRAero simu- lated the magnitude and timing of observed Saharan dust events during July 2009. Vertically, when compared to the CALIOP Level 3 gridded dust extinction product, MERRAero captured the observed magnitude and vertical extent of Saharan dust transport, although below $1 \mathrm{~km}$ altitude CALIOP reported extinction values that were much greater than those simulated in MERRAero. This finding is consistent with Amiridis et al. (2013), who demonstrated that the CALIOP feature-finding algorithm tends to exclude the marine layer embedded within dust layers, leading to a high bias in the retrieved extinction. This result highlights the importance of correctly identifying aerosol type when converting the backscatter profile to extinction via the lidar ratio. In our comparison to the CALIOP gridded Level 3 product, we discussed how the classification of marine layers as desert dust can result in higher extinction values for a given backscatter, as the lidar ratio for dust is greater than for marine aerosol.

For our analysis of MERRAero Saharan dust transport using the CALIOP VFM, we outlined two distinct strategies for creating VFMs based on MERRAero-simulated quantities. Our first method, the MERRAero-CALIOP method, was an attempt to directly apply the CALIOP VFM algorithm to MERRAero-simulated lidar profiles, and it required aerosol layer total attenuated backscatter, estimated particulate depolarization ratio and elevation, along with land surface type as 
inputs. This direct application of the CALIOP VFM is a simulation of how MERRAero quantities map to the CALIOP aerosol types following the CALIOP VFM algorithm logic and can be directly compared to the CALIOP VFM to assess transport biases for individual aerosol species in MERRAero. Our second MERRAero VFM is based on the fundamental outputs of the model, i.e., the speciated extinction, which leads to the so-called MERRAero-Extinction method. This approach required decisions regarding the prevalence of each individual type for it to be considered significant (e.g., in our case we assumed an aerosol type was significant if it contributed $25 \%$ or more to the total extinction). Our MERRAero-Extinction VFM can be compared to our MERRAero-CALIOP VFM to evaluate the performance of the CALIOP VFM, which we demonstrated to have significant implications for the CALIOP extinction product in Fig. 4.

Our comparison of the CALIOP and our MERRAero VFMs for July 2009 yielded several regional differences that have implications for dust transport in MERRAero and understanding limitations of the CALIOP VFM algorithm itself. Over northern Africa our MERRAero-CALIOP VFM compared very favorably to the CALIOP VFM by identifying desert dust as the dominant aerosol type, indicating that Saharan dust distributions in MERRAero over northern Africa are representative of what is observed by CALIOP. Similarly, our MERRAero VFMs both compared favorably over northern Africa, and it is a region where the CALIOP VFM algorithm performed well. Over the tropical North Atlantic, Caribbean, and eastern Pacific, our MERRAeroCALIOP VFM compared well with the CALIOP VFM at low altitudes. However, above $1 \mathrm{~km}$, the MERRAero-CALIOP VFM flags a significantly broader Saharan dust plume that extended further to the north, south, and west when compared to the CALIOP Saharan dust plume. Comparing our MERRAero VFMs downwind of the Saharan source region, particularly over the Caribbean, we found a greater occurrence of desert dust and polluted dust in our MERRAeroCALIOP VFM in regions that were flagged as dust-free in our MERRAero-Extinction VFM. This finding is consistent with Amiridis et al. (2013), who found that the use of the estimated particulate depolarization ratio and not the measured particulate depolarization ratio in the CALIOP VFM leads to an over-classification of dust/polluted dust layers.

Our construction of two MERRAero VFMs leads us to two major conclusions. The first conclusion that we found is MERRAero dust transport is too aggressive. This finding resulted from a comparison between the MERRAero-CALIOP VFM and the CALIOP VFM, as there was an increased prevalence of desert and polluted dust downwind of the Saharan source region in the MERRAero-CALIOP VFM. This result demonstrated the utility of using the CALIOP VFM for assessing biases in aerosol speciation in global models, as our AOTs were comparable to observations in this region, but our aerosol speciation in error.
Our second conclusion is that the CALIOP VFM algorithm is challenged when assigning an aerosol type when multiple aerosol types are present. This was demonstrated by comparing our MERRAero-CALIOP and MERRAeroExtinction VFMs from the MERRAero results (Fig. 7). Both of these synthetic VFMs see the same "truth" in the aerosol loading - that is, both are derived from the same aerosol distributions - and in certain areas show very different type identifications. A clear example of this can be seen over the Gulf of Guinea, west of southern Africa, where the MERRAero-Extinction method VFM identifies elevated smoke layers between the surface and about $4 \mathrm{~km}$, while the MERRAero-CALIOP VFM identifies marine aerosol. Lidar ratio assigned via these criteria would thus differ by more than a factor of 2 and so would lead to considerable error in the assigned extinction if the type is misidentified as suggested here (Campbell et al., 2012; Ford and Heald, 2012; Kanitz et al., 2014). In our evaluation of the Saharan dust plume, direct comparison between our MERRAero VFMs showed that the CALIOP VFM algorithm is biased toward classifying marine-dominated aerosol layers with low aerosol loadings that are mixed with small contributions from dust as polluted dust. This result suggests that using the estimated depolarization ratio alone can lead to biases in aerosol typing - particularly when multiple aerosol types are present and when the aerosol loading is low.

Our second conclusion is dependent on how we construct our MERRAero-Extinction VFM, which is designed to be representative of the actual aerosol types simulated in MERRAero. For the MERRAero-Extinction VFM, we first must make decisions regarding the mapping of GEOS-5 aerosols and aerosol mixtures to those of CALIOP. For our analysis, we only consider external mixing of aerosols. Internal mixing could impact the optical properties and lifetime of the aerosol via hygroscopic growth (Adachi and Buseck, 2008) in MERRAero. Additional uncertainty is potentially introduced through our threshold choices for the simulated extinction thresholds used to construct the MERRAero-Extinction VFM. We explored this sensitivity by varying the minimal aerosol species contribution to the total extinction between 10 and $40 \%$ and found an increase in the occurrence of desert dust vs. polluted dust over the tropical North Atlantic as the threshold was increased (not shown). Only when the minimum contribution from an individual aerosol species was lowered to $10 \%$ did we see a substantial increase in the extent of the Saharan dust plume. This supports our second conclusion and again highlights the challenge of classifying aerosol types when multiple aerosol types are present, as we found best agreement between our MERRAero VFMs when the minimum individual contribution to the total extinction was set at $10 \%$ in our MERRAero-Extinction method.

In addition to our methodology for constructing our MERRAero-Extinction VFM, another potential limitation of our evaluation is related to sampling. In this study, we sampled our simulated MERRAero aerosol distributions across 
altitudes of aerosol features observed by CALIOP. This limits our ability to identify cases where MERRAero might be simulating aerosols at too high of an altitude, as our methodology will cap the altitude range to what is observed by CALIOP. However, in order to apply the CALIOP VFM algorithm in the MERRAero-CALIOP method, we must adapt this methodology in order to compute the layer total attenuated backscatter and estimated particulate depolarization ratio for inputs into the CALIOP VFM.

In summary, our analysis illustrates the utility of the CALIOP VFM as a significant tool that may be used to evaluate aerosol transport in global aerosol transport models. From our analysis, we have diagnosed biases in aerosol transport in MERRAero and in the CALIOP VFM algorithm itself, which otherwise would not be possible using column AOT observations alone. Results from this work hint at future applications of this work. By comparing the MERRAero-CALIOP and MERRAero-Extinction VFMs, we have effectively performed an observing system experiment of precisely the kind that will be useful in developing future aerosol satellite missions. The model provides the "nature" state of the Earth system, and the algorithms may be tested against that state to isolate systemic errors in the algorithm. To our knowledge this is the first time this has been done with the CALIOP VFM.

Acknowledgements. We also would like to thank the CALIOP team for providing data obtained from the NASA Langley Research Center Atmospheric Science Data Center. Additionally, we would like to thank Brent Holben and Didier Tanré; Victoria Cachorro Revilla; Juan Antuqa Marrero; and Emilio Cuevas Agullo for their efforts in establishing and maintaining the La Parguera; Cabo Verde; Camaguey; and Santa Cruz, Tenerife AERONET sites, respectively. This work was funded by the NASA Postdoctoral Program (NPP) and under support from the Aerosol, Clouds, and Ecosystems (ACE) science working group, supported by Hal Maring.

Edited by: U. Wandinger

\section{References}

Abdou, W. A., Diner, D. J., Martonchik, V., Bruegge, C. J., Kahn R. A., Gaitley, B. J., Crean, K. A., Remer, L. A., and Holben, B.: Comparison of coincident MISR and MODIS aerosol optical depths over land and ocean scenes containing AERONET sites, J. Geophs. Res., 110, D02109, doi:10.1029/2008JD010754, 2005.

Adachi, K. and Buseck, P. R.: Internally mixed soot, sulfates, and organic matter in aerosol particles from Mexico City, Atmos. Chem. Phys., 8, 6469-6481, doi:10.5194/acp-8-6469-2008, 2008.

Adams, A. M., Prospero, J. M., and Zhang, C.: CALIPSO-Derived Three-Dimensional Structure of Aerosol over the Atlantic Basin and Adjacent Continents, J. Climate, 25, 6862-6879, 2012.
Amiridis, V., Wandinger, U., Marinou, E., Giannakaki, E., Tsekeri, A., Basart, S., Kazadzis, S., Gkikas, A., Taylor, M., Baldasano, J., and Ansmann, A.: Optimizing CALIPSO Saharan dust retrievals, Atmos. Chem. Phys., 13, 12089-12106, doi:10.5194/acp-1312089-2013, 2013.

Balkanski, Y., Schulz, M., Claquin, T., and Guibert, S.: Reevaluation of Mineral aerosol radiative forcings suggests a better agreement with satellite and AERONET data, Atmos. Chem. Phys., 7, 81-95, doi:10.5194/acp-7-81-2007, 2007.

Benedetti, A., Morcrette, J.-J., Boucher, O., Dethof, A., Engelen, R. J., Fisher, M., Flentje, H., Huneeus, N., Jones, L., Kaiser, J. W., Kinne, S., Mangold, A., Razinger, M., Simmons, A. J., and Suttie., M.: Aerosol analysis and forecast in the European Centre for Medium-Range Weather Forecasts Integrated Forecast System: 2. Data assimilation, J. Geophys. Res., 114, D13205, doi:10.1029/2008JD011115, 2009.

Browell, E. V., Carter, A. F., Shipley, S. T., Allen, R. J., Butler, C. F., Mayo, M. N., Siviter, J. H, and Hall, W. M.: NASA multipurpose airborne DIAL system and measurements of ozone and aerosol profiles, Appl. Optics, 22, 522-534, 1983.

Browell, E. V., Ismail, S., Hall, W. M., Moore, S. A., Kooi, S. A., Brackett, V. G., Clayton, M. B., Barrick, J. D. W., Schmidlin, F. J., Higdon, S., Melfi, S. H., and Whiteman, D. N.: LASE validation experiment. In Advances in atmospheric remote sensing with lidar, Springer Berlin Heidelberg, 289-295, 1997.

Buchard, V., da Silva, A. M., Colarco, P., Krotkov, N., Dickerson, R. R., Stehr, J. W., Mount, G., Spinei, E., Arkinson, H. L., and He, H.: Evaluation of GEOS-5 sulfur dioxide simulations during the Frostburg, MD 2010 field campaign, Atmos. Chem. Phys., 14, 1929-1941, doi:10.5194/acp-14-1929-2014, 2014.

Buchard, V., da Silva, A. M., Colarco, P. R., Darmenov, A., Randles, C. A., Govindaraju, R., Torres, O., Campbell, J., and Spurr, R.: Using the OMI aerosol index and absorption aerosol optical depth to evaluate the NASA MERRA Aerosol Reanalysis, Atmos. Chem. Phys., 15, 5743-5760, doi:10.5194/acp-15-57432015, 2015.

Burton, S. P., Ferrare, R. A., Vaughan, M. A., Omar, A. H., Rogers, R. R., Hostetler, C. A., and Hair, J. W.: Aerosol classification from airborne HSRL and comparisons with the CALIPSO vertical feature mask, Atmos. Meas. Tech., 6, 13971412, doi:10.5194/amt-6-1397-2013, 2013.

Buseck, P. and Posfai, M.: Airborne minerals and related aerosol particles: Effects on climate and the environment. Proceedings of the National Academy of Sciences of the United States of America, 96, 3372-3379, 1999.

Campbell, J. R., Hlavka, D. L., Welton, E. J., Flynn, C. J., Turner, D. D., Spinhirne, J. D., Scott, V. S., and Hwang, I. H.: Full-time, Eye-Safe Cloud and Aerosol Lidar Observation at Atmospheric Radiation Measurement Program Sites: Instrument and Data Processing, J. Atmos. Oceanic Technol., 19, 431-442, 2002.

Chen, Z., Torres, O., McCormick, M. P., Smith, W., and Ahn, C.: Comparative study of aerosol and cloud detected by CALIPSO and OMI, Atmos. Environ., 51, 187-195, 2012.

Chin, M., Ginoux, P., Kinne, S., Torres, O., Holben, B. N., Duncan, B. N., Martin, R. V., Logan, J. A., Higurashi, A., and Nakajima, T.: Tropospheric aerosol optical thickness from the GOCART model and comparisons with satellite and sun photometer measurements, J. Atmos. Sci., 59, 461-483, 2002. 
Colarco, P., da Silva, A., Chin, M., and Diehl, T.: Online simulations of global aerosol distributions in the NASA GEOS-4 model and comparisons to satellite and ground-based aerosol optical depth, J. Geophys. Res., 115, D14207, doi:10.1029/2009JD012820, 2010.

Colarco, P. R., Nowottnick, E. P., Randles, C. A., Yi, B., Yang, P., Kim, K.-M., Smith, J. A., and Bardeen, C. G.: Impact of Radiatively Interactive Dust Aerosols in the NASA GEOS-5 Climate Model: Sensitivity to Dust Particle Shape and Refractive Index, J. Geophys. Res., 119, 753-786, doi:10.1002/2013JD020046, 2014a.

Colarco, P. R., Kahn, R. A., Remer, L. A., and Levy, R. C.: Impact of satellite viewing-swath width on global and regional aerosol optical thickness statistics and trends, Atmos. Meas. Tech., 7, 2313-2335, doi:10.5194/amt-7-2313-2014, 2014b.

Daley, R.: Atmospheric Data Analysis, Cambridge University Press, 457 pp., 1991.

Dee, D. P. and Da Silva, A. M.: Maximum-likelihood estimation of forecast and observation error covariance parameters. Part I: Methodology, Mon. Weather Rev., 127, 1822-1834, 1999.

Dee, D. P., Rukhovets, L., Todling, R., Da Silva, A. M., and Larson, J. W.: An adaptive buddy check for observational quality control, Q. J. Roy. Meteor. Soc., 127, 2451-2471, 2001.

DeMott, P. J., Sassen, K., Poellot, M. R., Baumgardner, D., Rogers, D. C., Brooks, S. D., Prenni, A. J., and Kreidenweis, S. M.: African dust aerosols as atmospheric ice nuclei, Geophys. Res. Lett., 30, 1732, doi:10.1029/2003GL017410, 2003.

Diner, D. J., Beckert, J. C., Reilly, T. H., Brugge, C. J., Conel, J. E., Kahn, R. A., Martonchik, J. V., Ackermann, T. P., Davies, R., Gerstl., S. A. W., Gordon, H. R., Muller, J.-P., Myneni, R. B., Sellers, P. J., Pinty, B., and Verstraete, M. M.: Multi-angle Imaging SpectroRadiometer (MISR) - Instrument description and experiment overview, IEEE Trans. Geosci. Remote Sens., 36, 1072-1087, doi:10.1109/36.700992, 1998.

Dunion, J. P. and Velden, C. S.: The Impact of the Saharan Air Layer on Atlantic Tropical Cyclone Activity, B. Am. Meteorol. Soc., 85, 353-365, 2004.

Eck, T. F., Holben, B. N., Reid, J. S., Dubovik, O., Smirnov, A., O'neill, N. T., Slutsker, I., and Kinne, S., Wavelength dependence of the optical depth of biomass burning, urban, and desert dust aerosols, J. Geophys. Res.-Atmos., 104, 31333-31349, 1999.

Esselborn, M., Wirth, M., Fix, A., Weinzierl, B., Rasp, K., Tesche, M., and Petzold, A.: Spatial distribution and optical properties of Saharan dust observed by airborne high spectral resolution lidar during SAMUM 2006, Tellus B, 61, 131-143, 2009.

Evan, A. T., Dunion, J., Foley, J. A., Heidinger, A. K., and Velden, C. S.: New evidence for a relationship between Atlantic tropical cyclone activity and African dust outbreaks, Geophys. Res. Lett., 33, L19813, doi:10.1029/2006GL026408, 2006.

Ford, B. and Heald, C. L.: An A-Train and model perspective on the vertical distribution of aerosols and $\mathrm{CO}$ in the Northern Hemisphere, J. Geophys. Res., 117, D06211, doi:10.1029/2011JD016977, 2012.

Freudenthaler, V., Esselborn, M., Wiegner, M., Heese, B., Tesche, M., Ansmann, A., Müller, D. Althausen, D., Wirth, M., Fix, A., Ehret, G., Knippertz, P., Teledano, C., Gasteiger, J., Garhammer, M., and Seefeldner, M.: Depolarization ratio profiling at several wavelengths in pure Saharan dust during SAMUM 2006, Tellus B, 61, 165-179, 2009.
Gerber, H. E.: Relative-Humidity Parameterization of the Navy Aerosol Model (NAM). NRL Report 8956, 1-16, 1985.

Gong, S. L.: A parameterization of sea-salt aerosol source function for sub- and super- micron particles, Global Biogeochem. Cy., 17, 1097, doi:1029/2003GB002079, 2003.

Hagihara, Y., Okamoto, H., and Yoshida, R.: Development of a combined CloudSat-CALIPSO cloud mask to show global cloud distribution, J. Geophys. Res., 115, D00H33, doi:10.1029/2009JD012344, 2010.

Haywood, J., Francis, P., Osborne, S., Glew, M., Loeb, N., Highwood, E., Tanrè̀, D., Myhre, G., Formenti, P., and Hirst, E.: Radiative properties and direct radiative effect of Saharan dust measured by the C-130 aircraft during SHADE: 1 . Solar spectrum, J. Geophys. Res., 108, 8577, doi:10.1029/2002JD002687, 2003.

Hess, M., Koepke, P., and Schult, I.: Optical properties of aerosols and clouds: The software package OPAC, B. Am. eteorol. Soc., 79, 831-844, 1998.

Hill, C., DeLuca, C., Balaji, V., Suarez, M., da Silva, A., and the ESMF Joint Specification Team: The Architecture of the Earth System Modeling Framework, Comput. Sci. Eng., 6, 1-6, 2004.

Holben, B. N., Eck, T. F., Slutsker, I., Tanre, D., Buis, J. P., Setzer, A., Vermote, E., Reagan, J. A., Kaufman, Y. J., Nakajima, T., Lavenu, F., Jankowiak, I., and Smirnov, A.: AERONET-A federated instrument network and data archive for aerosol characterization, Remote Sens. Environ., 66, 1-16, 1998.

Holben, B. N., Tanré, D., Smirnov, A., Eck, T. F., Slutsker, I., Abuhassan, N., Newcomb, W. W., Schafer, J. S., Chatenet, B., Lavenu, F., Kaufman, Y. J., Vande Castle, J., Setzer, A., Markham, B., Clark, D., Frouin, R., Halthore, R., Karneli, A., O’Neill, N. T., Pietra, C., Pinker, R. T., Voss, K., and Zibordi, G.: An emerging ground-based aerosol climatology: Aerosol optical depth from AERONET, J. Geophys. Res., 106, 12067-12097, 2001.

Huang, H., Huang, J., Bi, J., Wang, G., Wang, W., Fu, Q., Li, Z., Tsay, S. C., and Shi, J.: Dust Aerosol Vertical Structure Measurements using three MPL Lidars during 2008 China-US Joint Dust Field Experiment, J. Geophys. Res., 115, D00K15, doi:10.1029/2009JD013273, 2010.

Huneeus, N., Schulz, M., Balkanski, Y., Griesfeller, J., Prospero, J., Kinne, S., Bauer, S., Boucher, O., Chin, M., Dentener, F., Diehl, T., Easter, R., Fillmore, D., Ghan, S., Ginoux, P., Grini, A., Horowitz, L., Koch, D., Krol, M. C., Landing, W., Liu, X., Mahowald, N., Miller, R., Morcrette, J.-J., Myhre, G., Penner, J., Perlwitz, J., Stier, P., Takemura, T., and Zender, C. S.: Global dust model intercomparison in AeroCom phase I, Atmos. Chem. Phys., 11, 7781-7816, doi:10.5194/acp-11-7781-2011, 2011.

IPCC: Intergovernmental Panel on Climate Change, Climate Change 2013: the Physical Science Basis: Working Group I Contribution to the IPCC Fifth Assessment Report, Cambridge University Press, 1535 pp., 2014.

Jenkins, G. S., Pratt, A. S., and Heymsfield, A.: Possible linkages between Saharan dust and tropical cyclone rain band invigoration in the eastern Atlantic during NAMMA-06, Geophys. Res. Lett., 35, L08815, doi:10.1029/2008GL034072, 2008.

Jickells, T. D., An, Z. S., Andersen, K. K., Baker, A. R., Bergametti, G., Brooks, N., Cao, J. J., Boyd, P. W., Duce, R. A., Hunter, K. A., Kawahata, H., Kubilay, N., laRoche, J., Liss, P. S., Mahowald, N., Prospero, J. M., Ridgwell, A. J., Tegen, I., and Torres, R.: 
Global iron connections between desert dust, ocean biogeochemistry, and climate, Science, 308, 67-71, 2005.

Johnson, B. T., Heese, B., McFarlane, S. A., Chazette, P., Jones, A., and Bellouin, N.: Vertical distribution and radiative effects of mineral dust and biomass burning aerosol over West Africa during DABEX, J. Geophys. Res., 113, D00C12, doi:10.1029/2008JD009848, 2008.

Kahn, R. A., Li, W.-H., Martonchik, J. V., Bruegge, C. J., Diner, D. J., Gaitley, B. J., and Abdou, W.: MISR calibration and implications for low-light-level aerosol retrieval over dark water, J. Atmos. Sci., 62, 1032-1052, 2005.

Kanitz, T., Ansmann, A., Foth, A., Seifert, P., Wandinger, U., Engelmann, R., Baars, H., Althausen, D., Casiccia, C., and Zamorano, F.: Surface matters: limitations of CALIPSO V3 aerosol typing in coastal regions, Atmos. Meas. Tech., 7, 2061-2072, doi:10.5194/amt-7-2061-2014, 2014.

Kaufman, Y. J., Tanré, D., Remer, D. L. Vermote, E. F., Chu, A., and Holben, B. N.: Operational remote sensing of tropospheric aerosol over land from EOS moderate resolution imaging spectroradiometer, J. Geophys. Res., 102, 17051-17067, 1997.

Kessner, A. L., Wang, J., Levy, R. C., and Colarco, P. R.: Remote sensing of surface visibility from space: A look at the United States East Coast, Atmos. Environ., 81, 136-147, doi:10.1016/j.atmosenv.2013.08.050, 2013.

Kim, D., Chin, M., Yu, H., Diehl, T., Tan, Q., Kahn, R. A., Tsigaridis, K., Bauer, S. E., Takemura, T., Pozzoli, L, Bellouin, N., Schulz, M., Peyridieu, S., Chédin, A., and Koffi, B.: Sources, sinks, and transatlantic transport of North African dust aerosol: A multimodel analysis and comparison with remote sensing data, J. Geophys. Res.-Atmos., 119, 6259-6277, doi:10.1002/2013JD021099, 2014.

Kinne, S., Schulz, M., Textor, C., Guibert, S., Balkanski, Y., Bauer, S. E., Berntsen, T., Berglen, T. F., Boucher, O., Chin, M., Collins, W., Dentener, F., Diehl, T., Easter, R., Feichter, J., Fillmore, D., Ghan, S., Ginoux, P., Gong, S., Grini, A., Hendricks, J., Herzog, M., Horowitz, L., Isaksen, I., Iversen, T., Kirkevåg, A., Kloster, S., Koch, D., Kristjansson, J. E., Krol, M., Lauer, A., Lamarque, J. F., Lesins, G., Liu, X., Lohmann, U., Montanaro, V., Myhre, G., Penner, J., Pitari, G., Reddy, S., Seland, O., Stier, P., Takemura, T., and Tie, X.: An AeroCom initial assessment - optical properties in aerosol component modules of global models, Atmos. Chem. Phys., 6, 1815-1834, doi:10.5194/acp-6-1815-2006, 2006.

Koehler, K. A., Kreidenweis, S. M., DeMott, P. J., Petters, M. D., Prenni, A. J., and Möhler, O.: Laboratory investigations of the impact of mineral dust aerosol on cold cloud formation, Atmos. Chem. Phys., 10, 11955-11968, doi:10.5194/acp10-11955-2010, 2010.

Kumar, P., Nenes, A., and Sokolik, I. N.: The importance of absorption for $\mathrm{CCN}$ activity and hygroscopic properties of mineral dust aerosols, Geophys. Res. Lett., 36, L24804, doi:10.1029/2009GL040827, 2009.

Lary, D., Remer, L. A., MacNeil, D., Roscoe, B., and Paradise, S.: Machine learning and bias correction of MODIS aerosol optical depth, IEEE Geosci. Remote S., 6, 694-698, doi:10.1109/LGRS.2009.2023605, 2010.

Lau, W. K. and Kim, K. M.: Cooling of the Atlantic by Saharan dust, Geophys. Res. Lett., 34, L23811, doi:10.1029/2007GL031538, 2007.
L'Ecuyer, T. S. and Jiang, J.: Touring the Atmosphere Aboard the A-Train, Phys. Today, 63, 36-41, 2010.

Levy, R. C., Remer, L. A., and Dubovik, O.: Global aerosol optical properties and application to Moderate Resolution Imaging Spectroradiometer aerosol retrieval over land, J. Geophys. Res., 112, D13210, doi:10.1029/2006JD007815, 2007a.

Levy, R. C., Remer, L. A., Mattoo, S., Vermote, E. F., and Kaufman, Y. K.: Second-generation operational algorithm: Retrieval of aerosol properties over land from inversion of Moderate Resolution Imaging Spectroradiometer spectral reflectance, J. Geophys. Res., 112, D13211, doi:10.1029/2006JD007811, $2007 \mathrm{~b}$.

Levy, R. C., Remer, L. A., Kleidman, R. G., Mattoo, S., Ichoku, C., Kahn, R., and Eck, T. F.: Global evaluation of the Collection 5 MODIS dark-target aerosol products over land, Atmos. Chem. Phys., 10, 10399-10420, doi:10.5194/acp-10-10399-2010, 2010.

Liu, Z., Omar, A. H., Hu, Y., Vaughan, M. A., Winker, D. M., Poole, L. R., and Kovacs, T. A.: CALIOP algorithm theoretical basis document, Part 3: Scene classification algorithms, NASA-CNES document PC-SCI-203, 2005.

Liu, Z., Omar, A., Vaughan, M., Hair, J., Kittaka, C., Hu, Y., Powell, K., Trepte, C., Winker, D., Hostetler, C., Ferrare, R., and Pierce, R.: CALIPSO lidar observations of the optical properties of Saharan dust: A case study of long-range transport, J. Geophys. Res.-Atmos., 113, D07207, doi:10.1029/2007JD008878, 2008.

Liu, Z., Kuehn, R., Vaughan, M., Winker, D., Omar, A., Powell, K., Trepte, C., Hu Y., and Hostetler, C.: The CALIPSO cloud and aerosol discrimination: Version 3 algorithm and test results, in: 25th International Laser Radar Conference (ILRC), St. Petersburg, Russia, 5-9 July 2010.

Loveland, T. R., Reed, B. C., Brown, J. F., Ohlen, D. O., Zhu, Z., Yang, L. W. M. J., and Merchant, J. W.: Development of a global land cover characteristics database and IGBP DISCover from 1 km AVHRR data, Int. J. Remote Sens., 21, 1303-1330, 2000.

Mahowald, N. M., Engelstaedter, S., Lou, C., Sealy, A., Artaxo, P., Benitez-Nelson, C., Connet, S., Chen, Y., Chuang, P. Y., Cohen, D. D., Dulac, F., Herut, B., Johansen, A. M., Kubilay, N., Losno, R., Maenhaut, W., Paytan, A., Prospero, J. M., Shank, L. M., and Siefert, R. L.: Atmospheric iron deposition: Global distribution, variability, and human perturbations, Annual Review of Marine Science, 1, 245-278, doi:10.1146/annurev.marine.010908.163727, 2009.

Matthias, V., Balis, D., Bosenberg, J., Eixmann, R., Iarlori, M., Komguem, L., Mattis, I., Papayannis, A., Pappalardo, G., Perrone, M. R., and Wang, X.: Vertical aerosol distribution over Europe: Statistical analysis of Raman lidar data from 10 European Aerosol Research Lidar Network (EARLINET) stations, J. Geosphys. Res., 109, D18201, doi:10.1029/2004JD004638, 2004.

McGill, M. J., Hlavka, D. L., Hart, W. D., Spinhirne, J. D., Scott, V. S., and Schmid, B.: The Cloud Physics Lidar: Instrument description and initial measurement results, Appl. Optics, 41, 37253734, 2002.

Meng, Z., Yang, P., Kattawar, G. W., Bi, L., Liou, K. N., and Laszlo, I.: Single-scattering properties of tri-axial ellipsoidal mineral dust aerosols: A database for application to radiative transfer calculations, J. Aerosol Sci., 41, 501-512, 2010.

Mielonen, T., Arola, A., Komppula, M., Kukkonen, J., Koskinen, J., de Leeuw, G., and Lehtinen, K. E. J.: Comparison of CALIOP level 2 aerosol subtypes to aerosol types derived from 
AERONET inversion data, Geophys. Res. Lett., 36, L18804, doi:10.1029/2009GL039609, 2009.

Mishchenko, M. I., Liu, L., and Mackowski, D. W.: T-matrix modeling of linear depolarization by morphologically complex soot and soot-containing aerosols, J. Quant. Spectrosc. Ra., 123, 135144, doi:10.1016/j.jqsrt.2012.11.012, 2013.

Nowottnick, E., Colarco, P., Ferrare, R., Chen, G., Ismail, S., Anderson, B. and Browell, E.: Online simulations of mineral dust aerosol distributions: Comparisons to NAMMA observations and sensitivity to dust emission parameterization, J. Geophys. Res.Atmos., 115, D03202, doi:10.1029/2009JD012692, 2010.

Nowottnick, E., Colarco, P., da Silva, A., Hlavka, D., and McGill, M.: The fate of saharan dust across the atlantic and implications for a central american dust barrier, Atmos. Chem. Phys., 11, 8415-8431, doi:10.5194/acp-11-8415-2011, 2011.

Omar, A. H., Won, J. G., Winker, D. M., Yoon, S. C., Dubovik, O., and McCormick, M. P.: Development of global aerosol models using cluster analysis of Aerosol Robotic Network (AERONET) measurements, J. Geophys. Res.-Atmos., 110, D10S14, doi:10.1029/2004JD004874, 2005.

Omar, A. H., Winker, D. M., Kittaka, C., Vaughan, M. A., Liu, Z., Hu, Y., and Hostetler, C. A.: The CALIPSO automated aerosol classification and lidar ratio selection algorithm, J. Atmos. Ocean. Tech., 26, 1994-2014, 2009.

Papayannis, A., Balis, D., Amiridis, V., Chourdakis, G., Tsaknakis, G., Zerefos, C., Castanho, A. D. A., Nickovic, S., Kazadzis, S., and Grabowski, J.: Measurements of Saharan dust aerosols over the Eastern Mediterranean using elastic backscatter-Raman lidar, spectrophotometric and satellite observations in the frame of the EARLINET project, Atmos. Chem. Phys., 5, 2065-2079, doi:10.5194/acp-5-2065-2005, 2005.

Pawson, S., Stolarski, R. S., Douglass, A. R., Newman, P. A., Nielsen, J. E., Frith, S. M., and Gupta, M. L.: Goddard Earth Observing System chemistry-climate model simulations of stratospheric ozone-temperature coupling between 1950 and 2005, J. Geophys. Res., 113, D12103, doi:10.1029/2007JD009511, 2008.

Putman, W. M. and Suarez, M.: Cloud-system resolving simulations with the NASA Goddard Earth Observing System global atmospheric model (GEOS-5), Geophys. Res. Lett., 38, L16809, doi:10.1029/2011GL048438, 2011.

Reale, O., Lau, W. -K., Kim, K. -M., and Brin, E.: Atlantic tropical cyclogenetic processes during SOP-3 NAMMA in the GEOS-5 global data assimilation and forecast system, J. Atmos. Sci., 66, 3563-3578, doi:10.1175/2009JAS3123.1, 2009.

Reale, O., Lau, K. M., Silva, A., and Matsui, T.: Impact of assimilated and interactive aerosol on tropical cyclogenesis, Geophys. Res. Lett., 41, 3282-3288, 2014.

Reid, J. S., Kinney, J. E., Westphal, D. L., Holben, B. N., Welton, E. J., Tsay, S.-C., Eleuterio, D. P., Campbell, J. R., Christopher, S. A., Colarco, P. R., Jonsson, H. H., Livingston J. M., Maring, H. B., Meier, M. L., Pilewskie, P., Prospero, J. M., Reid, E. A., Remer, L. A., Russell, P. B., Savoie, D. L., Smirnow, A., and Tanré, D.: Analysis of measurements of Saharan dust by airborne and ground-based remote sensing methods during the Puerto Rico Dust Experiment (PRIDE), J. Geophys. Res., 108, 8586, doi:10.1029/2002JD002493, 2003.

Remer, L. A., Kaufman, Y. J., Tanré, D., Mattoo, S., Chu, D. A., Martins, J. V., Li, R.-R., Ichoku, C., Levy, R. C., Kleidman, R. G., Eck, T. F., Vermote, E., and Holben, B. N.: The MODIS aerosol algorithm, products, and validation, J. Atmos. Sci., 62, 947-973, 2005.

Rienecker, M. M., Suarez, M. J., Todling, R., Bacmeister, J., Takacs, L., Liu, H.-C., Gu, W., Sienkiewicz, M., Koster, R. D., Gelaro, R., Stajner, I., and Nielsen, J. E.: The GEOS- 5 Data Assimilation System-Documentation of Versions 5.0.1, 5.1.0, and 5.2.0. Technical Report Series on Global Modeling and Data Assimilation, 104606, 92 pp., 2008.

Rienecker, M. M., Suarez, M. J., Gelaro, R., Todling, R., Bacmeister, J., Liu, E., Bosilovich, M. G., Schubert, S. D., Takacs, L., Kim, G.-K., Bloom, S., Chen, J., Collins, D., Conaty, A., da Silva, A., Gu, W., Joiner, J., Koster, R. D., Lucchesi, R., Molod, A., Owens, T., Pawson, S., Pegion, P., Redder, C. R., Reichle, R., Robertson, F. R., Ruddick, A. G., Sienkiewicz, M., and Woollen, J.: MERRA - NASA's Modern-Era Retrospective Anal- ysis for Research and Applications, J. Climate, 24, 36243648, doi:10.1175/JCLI-D-11-00015.1, 2011.

Rogers, R. R., Hair, J. W., Hostetler, C. A., Ferrare, R. A., Obland, M. D., Cook, A. L., Harper, D. B., Burton, S. P., Shinozuka, Y., McNaughton, C. S., Clarke, A. D., Redemann, J., Russell, P. B., Livingston, J. M., and Kleinman, L. I.: NASA LaRC airborne high spectral resolution lidar aerosol measurements during MILAGRO: observations and validation, Atmos. Chem. Phys., 9, 4811-4826, doi:10.5194/acp-9-4811-2009, 2009.

Rosenfeld, D., Rudich, Y., and Lahav, R.: Desert dust suppressing precipication: A possible desertification loop, P. Natl. Acad. Sci., 98, 5975-5980, 2001.

Russell, P. B., Livingston, J. M., Dutton, E. G., Pueschel, R. F., Reagan, J. A., DeFoor T. E., Box, M. A., Allen, D., Pilewskie, P., Herman, B. M., Kinne, S. A., and Hofmann, D. J.: Pinatubo and pre-Pinatubo optical depth spectra: Mauna Loa measurements, comparisons, inferred particle size distributions, radiative effects, and relationship to lidar data, J. Geophys. Res.-Atmos., 98, 22969-22985, 1993.

Ryder, C. L., Highwood, E. J., Rosenberg, P. D., Trembath, J., Brooke, J. K., Bart, M., Dean, A., Crosier, J., Dorsey, J., Brindley, H., Banks, J., Marsham, J. H., McQuaid, J. B., Sodemann, H., and Washington, R.: Optical properties of Saharan dust aerosol and contribution from the coarse mode as measured during the Fennec 2011 aircraft campaign, Atmos. Chem. Phys., 13, 303325, doi:10.5194/acp-13-303-2013, 2013.

Schuster, G. L., Dubovik, O., and Holben, B. N.: Angstrom exponent and bimodal aerosol size distributions, J. Geophys. Res.Atmos., 111, D07207, doi:10.1029/2005JD006328, 2006.

Schuster, G. L., Vaughan, M., MacDonnell, D., Su, W., Winker, D., Dubovik, O., Lapyonok, T., and Trepte, C.: Comparison of CALIPSO aerosol optical depth retrievals to AERONET measurements, and a climatology for the lidar ratio of dust, Atmos. Chem. Phys., 12, 7431-7452, doi:10.5194/acp-12-7431-2012, 2012.

Sessions, W. R., Reid, J. S., Benedetti, A., Colarco, P. R., da Silva, A., Lu, S., Sekiyama, T., Tanaka, T. Y., Baldasano, J. M., Basart, S., Brooks, M. E., Eck, T. F., Iredell, M., Hansen, J. A., Jorba, O. C., Juang, H.-M. H., Lynch, P., Morcrette, J.-J., Moorthi, S., Mulcahy, J., Pradhan, Y., Razinger, M., Sampson, C. B., Wang, J., and Westphal, D. L.: Development towards a global operational aerosol consensus: basic climatological characteristics of the International Cooperative for Aerosol Prediction Multi- 
Model Ensemble (ICAP-MME), Atmos. Chem. Phys., 15, 335362, doi:10.5194/acp-15-335-2015, 2015.

Shi, Y., Zhang, J., Reid, J. S., Liu, B., and Hyer, E. J.: Critical evaluation of cloud contamination in the MISR aerosol products using MODIS cloud mask products, Atmos. Meas. Tech., 7, 17911801, doi:10.5194/amt-7-1791-2014, 2014.

Smirnov, A, Holben, B. N., Eck, T. F., Dubovik, O., and Slutsker, I.: Cloud- screening and quality control algorithms for the AERONET database, Remote Sens. Environ., 73, 337-349, 2000.

Sokolik, I. N. and Toon, O. B.: Direct radiative forcing by anthropogenic airborne mineral aerosols, Nature, 381, 681-683, 1996.

Swap, R., Garstang, M., Greco, S., Talbot, R., and Kallberg, P., Saharan dust in the Amazon Basin, Tellus Ser. B, 44, 133-149, doi:10.1034/j.1600-0889.1992.t01-1-00005.x, 1992.

Tanré, D., Kaufman, Y. J., Herman, M., and Mattoo, S.: Remote sensing of aerosol properties over oceans using the MODIS/EOS spectral radiances, J. Geophys. Res.-Atmos., 102, 16971-16988, 1997.

Tegen, I. and Miller, R.: A general circulation model study on the interannual variability of soil dust aerosol, J. Geophys. Res., 103, 25975-25995, 1998.

Tesche, M., Ansmann, A., Müller, D., Althausen, D., Mattis, I., Heese, B., Freudenthaler, V., Wiegner, M., Esselborn, M., Pisani, G., and Knippertz, P.: Vertical profiling of Saharan dust with Raman lidar and airborne HSRL in Southern Morocco during SAMUM, Tellus B, 61, 144-164, 2009.

Tesche, M., Wandinger, U., Ansmann, A., Althausen, D., Müller, D., and Omar, A. H.: Ground-based validation of CALIPSO observations of dust and smoke in the Cape Verde region, J. Geophys. Res. Atmos., 118, 2889-2902, doi:10.1002/jgrd.50248, 2013.

Textor, C., Schulz, M., Guibert, S., Kinne, S., Balkanski, Y., Bauer, S., Berntsen, T., Berglen, T., Boucher, O., Chin, M., Dentener, F., Diehl, T., Easter, R., Feichter, H., Fillmore, D., Ghan, S., Ginoux, P., Gong, S., Grini, A., Hendricks, J., Horowitz, L., Huang, P., Isaksen, I., Iversen, I., Kloster, S., Koch, D., Kirkevåg, A., Kristjansson, J. E., Krol, M., Lauer, A., Lamarque, J. F., Liu, X., Montanaro, V., Myhre, G., Penner, J., Pitari, G., Reddy, S., Seland, Ø., Stier, P., Takemura, T., and Tie, X.: Analysis and quantification of the diversities of aerosol life cycles within AeroCom, Atmos. Chem. Phys., 6, 1777-1813, doi:10.5194/acp-6-1777-2006, 2006.

Vaughan, M. A., Winker, D. M., and Powell, K. A.: CALIOP algorithm theoretical basis document, part 2: Feature detection and layer properties algorithms, Rep. PC-SCI, 202, 87, 2005.

Wandinger, U., Tesche, M., Seifert, P., Ansmann, A., Müller, D., and Althausen, D.: Size matters: Influence of multiple scattering on CALIPSO light-extinction profiling in desert dust, Geophys. Res. Lett., 37, L10801, doi:10.1029/2010GL042815, 2010.

Welton, E. J., Voss, K. J., Gordon, H. R., Maring, H., Smirnov, A., Holben, B., Schmid, B., Livingston, J. M., Russell, P. B., Durkee, P. A., Formenti, P., and Andreae, M. O.: Ground-based Lidar Measurements of Aerosols During ACE-2: Instrument Description, Results, and Comparisons with other Ground-based and Airborne Measurements, Tellus B, 52, 635-650, 2000.
Welton, E. J., Campbell, J. R., Spinhirne, J. D., and Scott, V. S.: Global monitoring of clouds and aerosols using a network of micro-pulse lidar systems, in: Lidar Remote Sensing for Industry and Environmental Monitoring, edited by: Singh, U. N., Itabe, T., and Sugimoto, N., Proc. SPIE, 4153, 151-158, 2001.

Winker, D. M., Hostetler, C. A., Vaughan, M. A., and Omar, A. H.: CALIOP Algorithm Theoretical Basis Document, Part 1: CALIOP Instrument, and Algorithms Overview, Release, 2, 29, 2006.

Winker, D. M., Vaughan, M. A., Omar, A., Hu, Y., and Powell, K. A.: Overview of the CALIPSO mission and CALIOP data processing algorithms, J. Atmos. Ocean. Techn., 26, 2310-2323, 2009.

Winker, D. M., Tackett, J. L., Getzewich, B. J., Liu, Z., Vaughan, M. A., and Rogers, R. R.: The global 3-D distribution of tropospheric aerosols as characterized by CALIOP, Atmos. Chem Phys., 13, 3345-3361, doi:10.5194/acp-13-3345-2013, 2013.

Yasunari, T. J., Colarco, P. R., Lau, K.-M., Osada, K., Kido, M., Mahanama, S.P.P., Kim, K.-M., and da Silva, A. M.: Total Dust Deposition During Preciptiation in Toyama, Japan, in the Spring 2009: A Sensitivity Analysis with the NASA GEOS-5 Model, Atmos. Res., in press, 2015.

Yoshioka, M., Mahowald, N. M., Conley, A. J., Collins, W. D., Fillmore, D. W., Zender, C. S., and Coleman, D. B.: Impact of desert dust radiative forcing on Sahel precipitation: Relative importance of dust compared to sea surface temperature variations, vegetation changes, and greenhouse gas warming, J. Climate, 20, 14451467, 2007.

Yoshida, R., Okamoto, H., Hagihara, Y., and Ishimoto, H.: Global analysis of cloud phase and ice crystal orientation from Cloud Aerosol Lidar and Infrared Pathfinder Satellite Observation (CALIPSO) data using attenuated backscattering and depolarization ratio, J. Geophys. Res., 115, D00H32, doi:10.1029/2009JD012334, 2010.

Zhang, J. and Reid, J. S.: MODIS aerosol product analysis for data assimilation: Assessment of over-ocean level 2 aerosol optical thickness retrievals, J. Geophys. Res.-Atmos., 111, D22207, doi:10.1029/2005JD006898, 2006.

Zhang, J., Reid, J. S., Westphal, D. L., Baker, N. L., and Hyer, E. J.: A system for operational aerosol optical depth data assimilation over global oceans, J. Geophys. Res., 113, D10208, doi:10.1029/2007JD009065, 2008.

Zhu, A., Ramanathan, V., Li, F., and Kim, D.: Dust plumes over the Pacific, Indian, and Atlantic oceans: Climatology and radiative impact, J. Geophys. Res., 112, D16208, doi:10.1029/2007JD008427, 2007. 